\title{
農耕伝播による人類の森林破壞の 比較歴史地理学的研究
}

\author{
一ーイギリスと日本——
}

安田喜憲

は じめに

日本とイギリスが，文明の伝播・拡大の過程において，類似した地理的位置を占めて きたことは，つとに指摘されているところである(A.トインビー, 1967)。今, 農耕伝 播といら人類史に抢ける一つのエポックに焦点をあてた場合にも，共通した地理的条件 がみられる。すなわち中尾佐助 $(1966 \cdot 67)^{2)}$, 佐々木高明 $(1970 \cdot 71)^{3)}$ らによって指摘さ れている如く，日本は稻作を中心とする照葉樹林文化の北東端位置する。一方，イギ リスもまた，麦作を中心とする地中海農耕文化の北限にあたる。第 1 図には、これまで と明らかになったイギリスと日本への農耕文化の伝播経路と，農耕遺跡の $\mathrm{C}^{14}$ 年代測定 值を示した。この図から明らかの如く、イギリスと日本はともに農耕文化の発生地から みた場合, 辺境地方にあたるのである。第 2 の共通点は, これらの両地域へ農耕文化が 伝播するには，必ず海路を経なければならないことである。そうして第 3 は，これら二 つの島国の南部と北部において，植生に明膫な違いがあることである。すなわち，今西 錦司・吉良竜夫 (1953) の示したユーラシア大陸の生態系分布図 (第1図)によれば, イギリスの南部は落葉広葉樹林生態系に，北部は常緑針葉樹林生態系によって占められ ている。同様に日本の場合は，南西部は照葉樹林生態系に，東北部は落葉広葉樹林生態 系によって占められている。生態系列には，一つずれがあるものの，ともに北部にいく につれ，農耕には不適な自然条件が増大してくるのである。

ところで，人類はその出現以来，自然に大きく支配されてきた。それと同時にまた， 人類は自然の生態系をも大きく改変してきた。とりわけ植生は人為によって容易に改变

1) Toynbee, A. (1960): "A Study of History”, Oxford Univ. Press, (長谷川松治訳 (1967) 歴 史の研究 I 社会思想社).

2）中尾佐助（1966）：『栽培植物と農耕の起源』岩波新書，（1967）：「農業起源諭」「自然一生 態学的研究一』中央公論社.

3）佐々木高明 (1970):『熱帯の焼畑』古今畵院，（1971）:『稲作以前』 NH Kブックス.

4）今西錦司・吉良竜夫（1953）：「生物地理」福井英一郎編『自然地理 II』朝倉書店所収. 


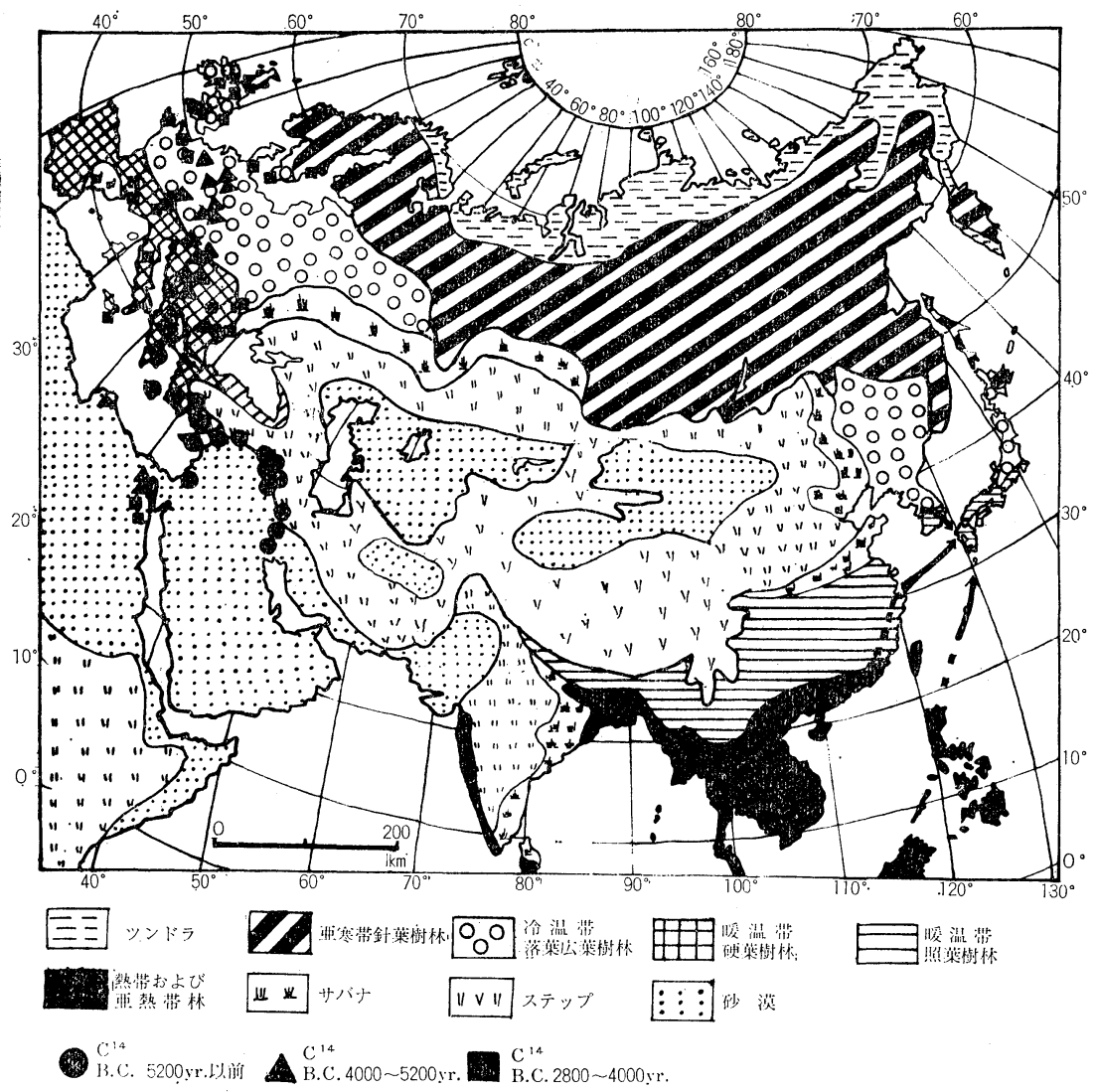

第 1 図 ニーラシア大陸の生態系と農耕伝播の径路

ユーラシア大陸の生態系は今西・吉良 (1953) にもとづき作成

農耕遺跡の C14 年代値は J.D. Clark（1965）による。

されるため，その影響は大なるものがあった。中でも農耕の導入は，狩猟採集経済に基 盤を抢く社会に比して，植生に対する人類の影響力を飛躍的に増大させた。人類の農耕 活動に伴ら火の使用, 開田作業, 材木の伐採, 家畜の放牧は, 居住地周辺の植生を大き く改変した。

今，こうした農耕の伝播による植物景観の変化に注目するならば，各地域における農 耕伝播の時期, ならびに農耕の発展段階の地域差が，人類の農耕活動による植生破壞の 時期ならびに植生破壞の様式の違いとして, 把握出来るものと考学られる。したがって, 
各地域に農耕が導入される以前の原植生を復原し，それが農耕の伝播によって，いつ頃， いかに改変されたかを論ずるならば，農耕の伝播と拡大の過程，ならびにその生態学的 意味を，より明白にすることが出来るはずである。

すでに述べたイギリスと日本の, 農耕伝播に際しての共通した 3 つの地理的条件は, 植物景観の変遷を通して, 農耕の伝播・払大の過程を比較歴史地理学的に論ずるのに好 都合となる。すなわち, 第 1 の農耕文化の発生地からみた場合, ともに辺境地方にあた るといら条件は,これまで人類によって大きな自然の生態系の破壞を受けていない開発 のフロンティアとしての辺境地方にあっては, 新しい農耕文化をもった開拓者の侵入に よる自然植生の破壤が, よりリアルに捉えることが出来る。また第 2 の, 農耕文化の伝 播に際してともに海路を経なければならないという条件は，海路による伝播は，陸路よ り困難であり，伝播地が限られ，伝播地からの農耕文化の拡大の跡が追跡しやすい。ま た第 3 の列島の北部にいくにつれ，農耕には不利な自然条件が増大することは，農耕文 化の伝播と自然条件とのかかわりあいを明確に取り上げることが出来る。特に気候条件 の変化は, 植生の違いとして反映し, 農耕伝播による植生と人類のかかわりあいの変化 を，史的に究明するのに都合がよい。

本稿の第 1 の目的は, こうした農耕伝播に伴ら人類の森林破壞に注目し, 植物景観変 遷の復原を通して, 農耕伝播の時期, ならびに拡大の過程を, イギリスと日本の比較に おいて考察するところにある。

しかしながら, 農耕伝播に際してのイギリスと日本の類似した地理的条件に対し, 決 定的に異なるものがある。それは, 同じ農耕文化でありながら, 片や稲作中心の農耕で あるのに対し，他方は麦作中心の農耕形式をとることである。この地中海性気候の下に 成立した麦作中心の農耕と, 熱帯モンスーンを故郷とする稲作中心の農耕の生態学的相 違については, 中尾佐助 (1967) の論考に詳しい。とりわ忷, 「地中海農耕文化は, 耕 作開始の初期引ら家畜が関係して，その技術的展開が常に家畜の利用と結合して進んだ のに対し，稲作中心の農耕では，こうした積極的な家畜との結合がみられないこと。ま た地中海農耕文化では，大面積を粗雑ながら利用する形態がとられ，麦類の中に多数の 禾本科植物や広葉草本が混じり，それらが麦作特有の雑草群を作り上げている。一方， 稲作農業の場合は, 大河の下流域の沖積平野を中心とし, 除草が入念に行なわれ, 特有 な雑草の存在を認め得ない」(p.p.430～431) などの相違点は, 農耕伝播によって引き 起こされた植物景観の变遷を論ずる場合，見逃し得ない事実となる。このイギリスと日

5）中尾佐助 (1967)：前揭. 
本における農耕形式の違いは, 農耕伝播に伴ら人類の植生破壇の椂式に大きな違いをも たらしたものと考光られる。

本稿の第 2 の目的は, イギリスと日本といら類似した地理的条件を有する地域におい て,こらした農耕形式の違いが, 農耕の伝播によって引き起された植物景観変遷の様式 に，いかなる相違を生じさせたかを，比較歴史地理学的に究明するところにある。

ところで, こうした農耕伝播に伴う人類の森林破壊の時期と様式を論ずる手段として, 最も有効なのは花粉分析である。花粉分析はもともとは, 植生の変化から過去の気候変 化を究明することに，多く使われてきた。しかし，新石器時代の植生変化は，たんに気 候変化のみによって引き起されたものでないことが，しだいに明らかになってきた。本 稿では，この花粉分析の使用により，農耕伝播による植物景観変遷の時期と䇐式を、イ ギリスと日本の比較において論じてみたい。

\section{1 ギリ ス}

古代におけるイギリスの景観については, カエサルの「ガリア戦記」， タキトゥスの 「ゲルマーニアリなどから知ることが出来るよらに, 現在よりるはるかに深く森林によ ってお和われていた。先史時代から現代に至る植物景観の変遷は, 気候变化・土壤侵食 などの自然的条件によるのみでなく，人類による植生に対する干渉 (impact) が大きな 役割を果たしている。H.C. Darby (1956) は，古記録の整理により，こうしたヨーロ ッパに拉ける人類の森林破壞の歴史を明らかにした。一方, 先史・歴史時代に拈ける植 生を復原する手段に, 花粉分析がある。この花粉分析が人類を取り巻く植物景観变遷の 追求の中でクローズアップされてきたのは，V.R. Gradmann（1901・06）のステッペ ソハイデ説に対する反論の中からであった。このステッペンハイデ説をめぐる論争の契 機については, 水津一朗 (1950), 佐々木高明 (1965), 千田稔 (1970) の論考に詳しい。

こうしたヨーロッパにおける趨勢の中で, イギリスに括いても, 先史・歴史時代の人 類と植生のかかわりあいが注目されてきた。まず植生を人類の歴史のバックグラウンド

6）カエサル著，近山金次訳（1942）：『ガリア戦記』岩波文庫，

7）タキトゥス著，田中・泉井共訳（1953）：『ゲルマニア』岩波文庫.

8) Darby, H.C. (1956): "The clearing of the woodland in Europe" Man's role in changing the face of the earth, London 所收.

9) Gradmann, R. (1901): "Das mitteleuropäische Landschaftsbild nach seinen geschichtlichen Entwicklung" Geog. Zeit. vol.7, (1906): "Beziehung zwischen Pflanzengeographie und Siedlungsgeschichte" Geog. Zeit. vol. 12.

10）水津一朗（1950）：ヨーロッパ集落の生態, 史林 33 .

11）佐々木高明 (1965): 焼畑農業の研究々その課題, 人文地理 vol.17.

12）千田稔 (1970)：農耕の発生・伝播についての景観論的研究, 人文地理 vol. 22. 
として捉えた研究として， B. W.H. Pearsall \& W. Pennington (1947) の研究をあげ ねばなるまい。陸上に拈ける植生変化と, 湖底泥の $\mathrm{C} / \mathrm{N}$ 比の分析により，人類による 植生破壞をエコロジカルな観点から巧みに論じている。この時期を代表するものとし て, この他に E. J. Salisbury \& F. W. Jane (1940) の研究がある。

1950年代に入ると，これまでの研究の集大成ともいうべき，H. Godwin (1956) の “The history of the British flora”が刊行された。特に彼は, 第四紀に和ける気候変化 によって引き起こされた植生変化と，人類の impact の結果引き起こされた㥀生変化を 区別することに注意を払っている。 $\mathrm{C}^{14}$ 年代測定法の開発は, 植生変化の時期を決定す ることを可能にし，これまでの研究に飛躍的な発達をもたらした。その研究成果の集 大成として，D. Walker \& R. G. West（1970）によって編集された“Studies in the vegetational history of the British Isles”が刊行された。

今日では, 花粉分析の方法も発達し，その分析も， $0.5 \sim 0.2 \mathrm{~cm}$ の細かさで行なわれ るようになった。また $\mathrm{C}^{14}$ 年代測定を併用することによって，人類による植生破壊の実 態が明白になりつつある。とりわけ，J. Turner (1965) は，人類の生産様式の発展段階 に対応して，植生破壊の程度にも三段階があることを述べている。すなわち，その第 1 段階は，一時的な植生破壊の段階で，Gramineae, Plantago, Artemisia などの，農耕 と密接なかかわりあいのある草本花粉の出現率が，木本花粉に対して，20\%前後出現す る状態をいう。第 2 段階は, 広範な植生破壊の段階で, 木本花粉に対する Gramineae などの草本花粉の出現率が $100 \%$ 以上に達する段階をいう。そうして, 第 3 段階は現在 の植物景観を形成するに至った完全なる植生破壞の段階である。この段階では，木本花 粉に対する Gramineae, Artemisia などの花粉が $200 \%$ 以上の出現率を示す。以下にお いて筆者がイギリスの各地域に晾ける分析結果を取り上げる祭にも，この J. Turnerの 三段階説に従って考察を加える。

\section{I-（1） 新石器時代遺跡の分布}

13) Pearsall, W.H. \& Pennington, W. (1947): "Ecological history of the English Lake District" The Journal of Ecology, vol. 34.

14) Salisbury, E. J. \& Jane, F. W. (1940): "Charcoals from midden Castles and their significance in relation to the vegetation and climatic conditions in prehistoric times" The Journal of Ecology, vol. 28.

15) Godwin, H. (1956): "The history of the British flora" London.

16) Walker, D. \& West, G. (ed.) (1970): "Studies in the vegetational history of the British Isles" Cambridge.

17) Turner, J. (1965): "A contribution to the history of forest clearance". Proc. Roy. Soc. B. vol. 161 . 
イギリスにおける代表的な新石器時代遺跡の分布は, 第 5 図に示す如くである。最も 初期の農耕遺跡は Shippea Hill 遺跡で, C14 年代測定で B. C. 3, 400 120 年の值が出 ている。その他 Windmill Hill 遺跡に拈いては B. C. 2,850土150年, Hembar 遺跡に掠 いては B. C. 2,975 134 年の值が得られている（第 5 図) (J. D. Clark \& H. Godwin, 1962)。このことから，イギリスに新石器文化が伝播したのは B. C. 3,400 年頃のこと であることがわかる。これはイランのアナトリア高原で初期の農耕遺跡が B. C. 6,000 年前後の $\mathrm{C}^{14}$ 年代を得ている（第 1 図）のに比べて, 約 2,500 年の隔たりがある (J.D. Clark, 1965)。そうして, イギリスの北部にいくにつれ, 農耕遺跡の出現時期は新しく なる。また遺跡の分布においては, イギリス南部のいわゆる石灰岩地帯と, 南東部の海 岸地帯に集中し, 北部にいくにつれ，次第に少なくなる(S. Piggot, 1965)。B. C. 2, 500 〜B.C. 1, 800 頃に作られたとみられる Megalithic Tomb の分布 (G. Daniel, 1950) をみても，南部の石灰岩地帯と南西部の海岸地带に多いことが注目される。

こうした南部と北部に挌ける遺跡分布密度の違い, あるいは時代の差は, 人類による 植生破壞の時期ならびに植生破壊の程度にも, 大きな違いをもたらしたものと考えられ る。次にこうした農耕伝播に伴う人類の森林破壊の地域性を究明するため, 各地域の花 粉分析結果を比較検討してみる。

\section{I-（2） 各地域の花粉分析結果}

(1) Norfolk 州 Old Buckenhammere (H. Godwin, 1967)

イギリス北東部の Norfolk 州の 小さな湖 Old Buckenhammere（第 5 図一(1)）は, 1962 1963年の寒波の際, 湖沼全域が凍結した。そこで氷の上からボーリングによって, 湖底泥の採集を行ならことが出来, この湖底泥の花粉分析が行なわれた。分析にあたっ ては，150 個以上の木本花粉が同定されている。この花粉分析の結果からは，人類の植 生に対する影響と, それを裏付ける考古学的・歴史的事実がうまく対応するところが注 目される。

最初の人類の植生破壞の痕跡がみられるのは B. C. 3, 000 年頃である。そこでは Plantago, Artemisia, Rumex, Ranunculus などの花粉が増加している。しかし出現率はわ

18) Clark, J. D. \& Godwin, H. (1962): "The Neolithic in the Cambridgeshire Fens" Antiquity, vol. 34 .

19) Clark, J.D. (1965): "Radiocarbon dating and the expansion of farming culture from the Near East over Europe" Proceedings of the Prehistoric Society, vol. 35. London.

20) Piggot, S. (1965): "Ancient Europe", Edinburgh.

21) Daniel, G. (1950): "The prehistoric chamber Tombs of England and Wales", Cambrige.

22) Godwin, S. (1962) : "Vegetational history of the Kentish Chalk downs as seen at Wingham and Frogholt" Veröff. Geobot. Inst. Kübel, vol. 37. 
ずかであり，小規模な一時的森林破壊の段階にとどまっている。ところが Pre-Roman 期から Roman 期の鉄器時代に入ると, 急速な森林破壊が引き起こされた。Gramineae の出現率は $100 \%$ 以上に達し，この時代に広範な植生破壊に達したことがわかる。この 広範な植生破壞は, 牧畜によって引き起こされたものと考えられている。それは牧草地 特有の花粉である Plantago, Pteridium の出現が多いことから推察される。ところが A. D. 400 年頃になると, 草本類の中で, Compositae, Chenopodium, Artemisia などの, 農耕地特有の花粉が多く出現してくる。これは, この時代に牧畜中心の農業から穀物栽 培中心の農業へ変化したことを示している。この変化は, アングロサクソン人のこの 地域への侵入期とほぼ対応している。A.D. 1,500 年前後に拈いて, Gramineae, Cyperaceae の花粉出現率が $200 \%$ 以上に達し，完全なる 植生破壞の段階に入ったことが知 られる。

(2) Cambridge 州 Shippea Hill 遺跡 (J. D. Clark \& H. Godwin, 1962)

イギリス南東部の Camdridge 州 Shippea Hill 遺跡（第5図一(2)）は, Roddon 川 の自然堤防と旧河道に沿って立地し, 青銅器時代一新石器時代一中石器時代の 3 文化層 を有する。この遺跡の発掘は, すでに1933・34年に行なわれており, その際, D. J. Iversen らによって不完全ながら花粉分析も行なわれている。1960年, 新たに花粉分析と 出土層位確認のため, 発掘が行なわれた。

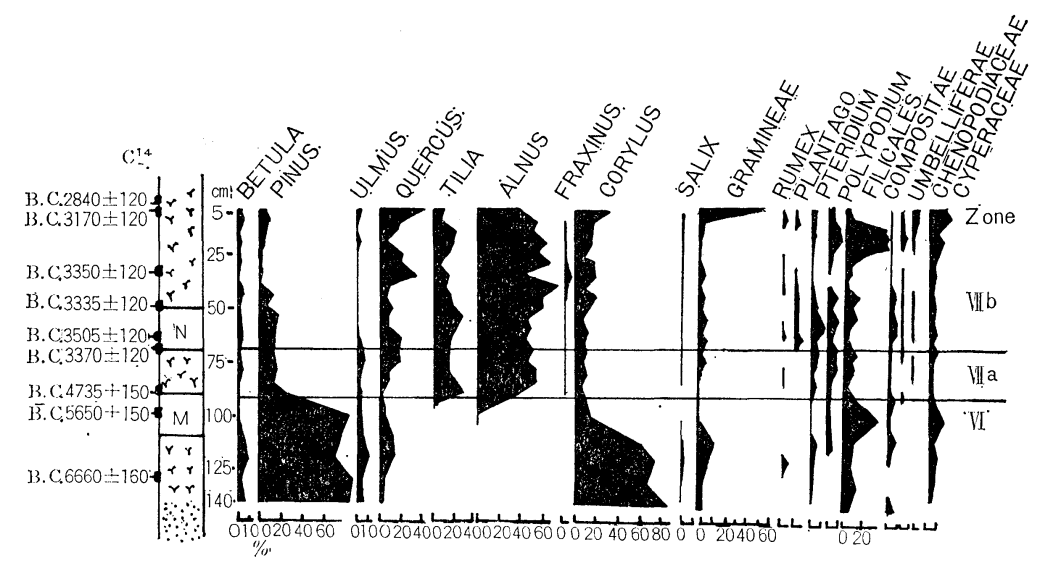

第 2 図 Cambridge 州 Shippea Hill 遺跡の分析結果

(J.D. Clark, \& H. Godwin, 1962)

23) Clark, J. D. \& Godwin, H. (1962) : "The Neolithic in the Cambridgeshire Fens" Antiquity, vol. 34 . 
遺跡の断面は，厚さ 1 1.5 mの粘土層をはさんで，上・下 2 枚の泥炭層が，基底の 玄武岩質砂層の上に堆積している。上部泥炭層からは，初期青銅器時代の遺物が出土す る。一方, 下部泥炭層は, 地表下 $2.3 \sim 5 \mathrm{~m}$ 付近に発達し, その上部からは新石器時代 の遺物が，その下部からは中石器時代の遺物が出土する。

青銅器時代の遺物を出土する上部泥炭層は，人工的に掘り返しが行なわれているため， 花粉分析による植生変化の追求は，難しい。ここで花粉分析が行なわれたのは，下部の 新石器時代と中石器時代の遺物を含有する層についてである。分析にあたっては, $5 \mathrm{~cm}$ 毎にサンプリングされた試料について，200～300個以上の木本花粉が同定されている。 とりわけこの分析結果においては， $\mathrm{C}^{14}$ 年代測定值が多く示されている。花粉ダイアグ ラムは, 第 2 図に示す如く, 下層から Zone VI, Zone $\mathrm{VII}_{\mathrm{a}}$, Zone $\mathrm{VII}_{\mathrm{b}}$ の 3 花粉帯 に区分される。Zone VI は Pinus, Corylus の出現が圧倒的に多く，この他，Ulmus， Quercus が10～20\%の出現率を示す。Zone VII に入ると，Pinus, Corylus の花粉は急減 し，これに代わって Tilia, Alnus の花粉が急増する。Zone $\mathrm{VII}_{\mathrm{b}}$ に入るとUlmusの花 粉が減少傾向を示し始め, 森林破壞の指示者的な位置を占める Plantago, Compositae, Ranunculus, Pteridium などの草本花粉が増加する。C14 年代測定によれば, Zone VI と Zone $\mathrm{VII}_{\mathrm{a}}$ の境界は B.C. 4,800年前後, Zone $\mathrm{VII}_{\mathrm{a}}$ と Zone $\mathrm{VII}_{\mathrm{b}}$ の境界は B.C. 3, $370 \pm 120$ 年の值が出ている。Zone VI からZone VII への植生变化は, 寒冷なボ レアル期から温曖なアトランティック期への気候変化に 原因が求められる。ところが Zone $\mathrm{VII}_{\mathrm{a}}$ から Zone $\mathrm{VII}_{\mathrm{b}}$ への変化は，人類による森林破堎の結果であると考えられ る。 $\mathrm{C}^{14}$ 年代で B. C. $3505 \pm 120$ 年の值を得た層準からは，羊の遺体が発見されて和り， 家畜を伴った人類による森林破壞が考学られている。しかし Gramineae の出現率は少 なく，この森林破壞は小規模なものであったと考觉られている。中石器時代の遺物含有 層では，人為による森林の破壤はみられない。花粉ダイアグラムの下部に和ける $T y$ pha, Cyperaceae, Gramineae の増加は, いずれも湿原の桩大の結果によるものであっ て，人類による森林破壞の結果ではないとされている。

(3) Kent 州 Frogholt (H. Godwin, 1962)

南東部の石灰岩地帯の代表例として，Kent 州 Frogholt の Seabrook 谷の分析結果 を上げる（第 5 図一(3)）。この地域は 新石器時代の遺跡が多く分布するところである。 分析された泥炭は B.C. 1, 200年頃から堆積が始まり，B.C. 530 年で堆積を終了してい

24) Godwin, S. (1962) : "Vegetational history of the Kentish Chalk downs as seen at Wingham and Frogholt” Veröff. Geobot. Inst. Kübel, vol. 37. 
る。基底から Gramineae, Compositae, Pteridium などの草本花粉の出現率が高い。 $\mathrm{C}^{14}$ 年代 B. C. 1, 120 年のところでは, Gramineae の花粉が100\%以上の出現率を示し， 広範な植生破壞の段階に入っていたことがわかる。C 14 年代 B. C. 680 年の付近において は, Gramineae, Compositae, Pteridium などの花粉, 胞子の出現率が 300\% 以上飞達 し，この時代に完全なる植生破壊の段階に入っていたことがわかる。すでにこの $\mathrm{C}^{14}$ 年 代 B.C. 680 年頃に，現在の植物景観に近いものが形成されていた事実は注目される。 石灰岩地带では，一旦森林が切り払われると土壤侵食が激しく引き起こされ，森林の回 復が困難であるといら自然的条件の他に，古くから居住が行なわれ，人類による植生破 壤が継続的に行なわれたことも，大きな要因をなすものとみなければならない。

(4) Cardigan 州 Tregaron Bog (J. Turner, 1970)

南西部の Cardigan 州（第 5 図一(5)）の分析結果を第 3 図に示す。C14 年代 B. C. 400 年以前に扔いては, 草本類の Gramineae, Plantago などの花粉出現率が 10〜 40\% 内外 を占め, 一時的な植生破壞の段階を示している。この一時的な植生破壊の後, Corylus, Alnus などの木本花粉の出現率が再び増加し，草本類の花粉が減少する。これは人類の 居住が中断され，再び森林が回復したことを物語る。C $\mathrm{C}^{14}$ 年代 B. C. 400 年から A. D.

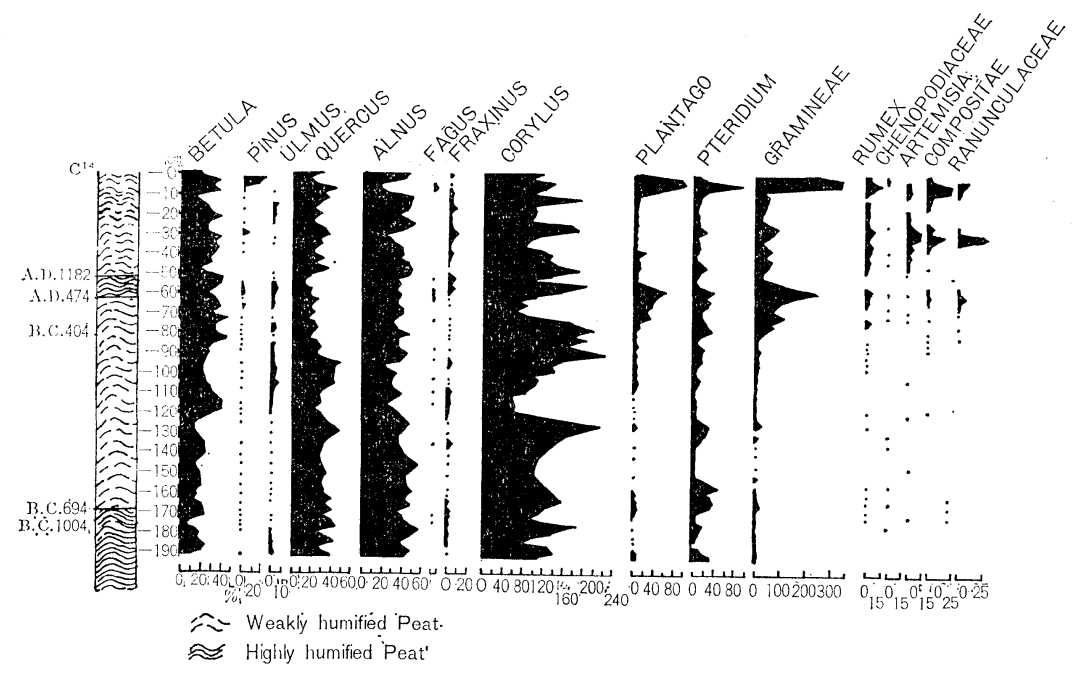

第 3 図 Cardigan 州 Tregaron Bog の分析結果 (J. Turner 1970)

25) Turner, J. (1970): "Post-neolithic disturbance of British vegetation" Walker, D. \& West, G. (ed.) (1970): Studies in the Vegetational history of the British Isles, Cambridge, 所收. 
1,200年の間に括いては, Gramineae, Plantago,Pteridium などの出現率が100〜200\% 前後を示す。これに対しQuercus, Corylus などの木本花粉が減少している。これは広 範な植生破壊の段階を示するのである。C 14 年代 B. C. 400年頃を境として，それ以前と 以後とでは，人類の植生に対する働きかけが大きく異なったことを示す。この B.C. 400年頃は，この地域へ鉄器が伝播した時期にあたり，鉄器の使用が人類の植生破壤を 大きく前進させたことが知られる。地表下 $10 \mathrm{~cm}$ の層準で，草本花粉の出現率は $200 \%$ 以上に達し, 完全なる植生破壊の段階に達したことが知られる。

さらに草本花粉の出現をより細かにみると，各時代によって出現率の構成が異なる。 すなわち地表下 $10 \mathrm{~cm}$ までは, 牧草地特有の Plantago, Pteridium などの出現率が高 い。これに対し, 地表下 $10 \sim 58 \mathrm{~cm}$ の間では, 農耕地特有の Artemisia, Rumex, Compositae, Ranunculaceae などの出現率が高くなる。そうして，地表下 $59 \sim 80 \mathrm{~cm}$ の間 に执いて Plantago, Pteridium などの牧草地特有の花粉の出現率が再び高くなる。地表 下 $80 \mathrm{~cm}$ 以下 ( ${ }^{14}$ 年代 B. C. 400 年以前) に招いては, Gramineae の出現率は 10 20 \%にとどまる。このことから，B.C. 400 年以前に拈いては原始的な農業が行なわれ，そ の後, 地表下 $58 \mathrm{~cm}$ の A.D. 500 年頃までは牧畜中心の農業が行なわれ, A. D. 500 年以 降17〜18世紀頃までは穀物栽培を中心とする農業が，そうして地表下 $10 \mathrm{~cm}$ より上部に おいては再び牧畜中心の農業が行なわれたことが明らかになった。そらして，B.C. 400 年頃を境とする原始的農業から牧畜中心の農業への転化は, この地域に鉄器文化が流入 した時期にあたっている。また A. D. 500 年以降の豰物栽培を中心とする農業の開始は， アングロサクソン人の侵入により，有輪犁を伴った農耕が伝播したことによる。そうし て，17〜18世紀以降の牧畜中心の農業への転化は, 浮田典良（1970）によっても述べら れている如く, 近年のヨーロッパ全体に拈ける主畜化の傾向を反映したものである。

以上南部地域に和㤃る分析結果をみてきたが, 南部地域は, この他, Somerset Level Raised Bog, (H.S. L. Dewar \& H. Godwin, 1963) (第5図一(4)) Shrop 州の Wixall Moss (J. Turner, 1965) (第5 図一(6) の分析結果などがある。いずれも, すでに述 べた分析結果と類似の傾向を示す。次に北部地域に怙ける分析結果をみよう。

(5) Ayr 州 Bloak Moss (J. Turner, 1970)

26）浮田典良 (1970):『北西ドイツの歴史地理学的研究』大明堂.

27) Dewar, S. L. \& Godwin, H. (1963): "Archaeological Discoveries in the Raised Bogs of the Somerset Levels, England" Proceeding of the Prehistoric Society, vol. 29. London.

28) Turner, J. (1965): ibid.

29) Turner, J. (1970) : ibid. 
北部地域に拈ける分析結果として, Ayr 州の Bloak Moss の分析結果を取り上げる (第 5 図一8)。この花粉ダイアグラム（第 4 図）で，人類による植生破壞の痕跡がみら れるのは，地表下 $240 \mathrm{~cm}$ の層準からである。人為的影響がみられてからの花粉ダイア グラムは, 7つの Sub-Zone に分けられる。

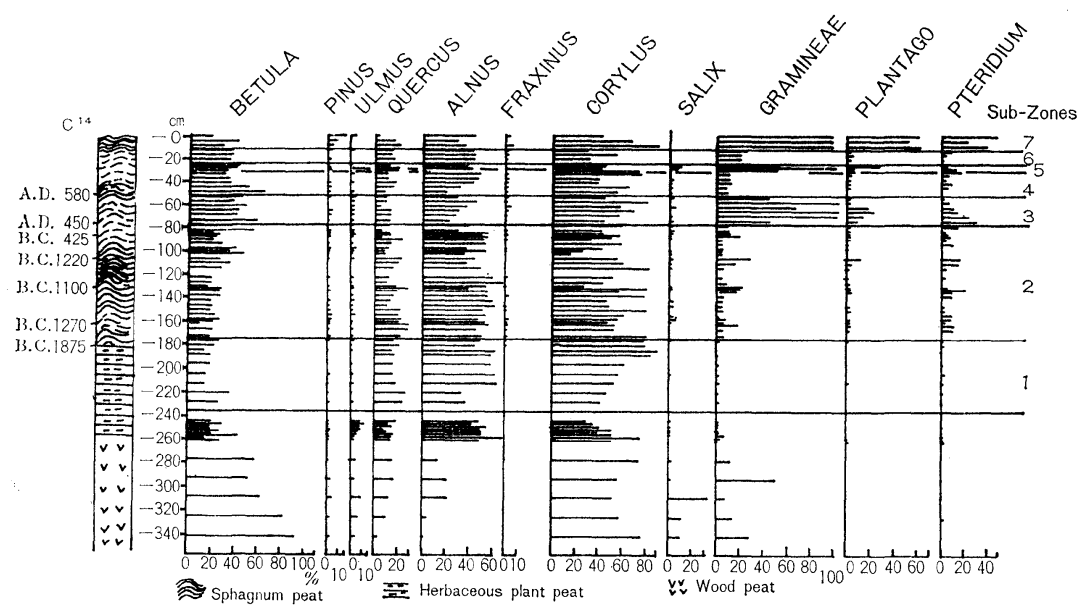

第 4 図 Ayr 州 Bloak Moss の分析結果 (J. Turner 1965)

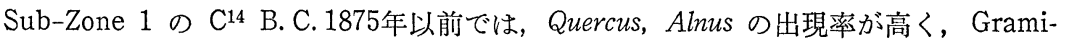
neae や Plantago は，わずかしか出現しない。ただ Corylus の花粉が増加することか ら, 人類の居住していた可能性が強いとされる、おそらく新石器時代人は, 森林そのも のを破壊することなく，その産物を利用して生活していたのであるら。Sub-Zone 2 に 入ると，地表下 $110 \mathrm{~cm}, 134 \mathrm{~cm}, 166 \mathrm{~cm}$ のところで, Gramineae, Plantago, Pteridium の花粉が増加している。しかし，その増加は連続的ではなく，突発的である。これは， すでに J. D. Iversen (1949) によって示された結果とよく似ている。つまり一時的に 人類によって破壞された植生が，人類の居住地の放棄によって，再び森林に再生するの である。この一時的森林破壊の継続期間は，泥炭の堆積速度から約 50 年位であるとみな されている。 $\mathrm{C}^{14}$ 年代測定から, この一時的森林破壤が引さ起こされ, 再び森林が回復 した期間は，B.C. 1, 400年〜B. C. 1,000年の間であるとみなしらる。

Sub-Zone 3 に入ると，Gramineae の出現率が 100\%に達し，広範な植生破壞の段

30) Iversen, J. (1949) : "The influence of Prehistoric Man on Vegetation" Geol. Unders. vol. 4. 
階に入ったことを示している。しかし，この段階は，A. D. 450〜580 年の間続いたのみ で, その後, 急激に Gramineae の花粉は減少し, 再び Corylus, Alnus, Quercus など の木本花粉が增加する。これは明らかに, 農耕の廃止と森林の再生を物語るものである。 この森林の復活期が Sub-Zone 4 にあたる。その後 Sub-Zone 5 に至って, 再び農耕 が開始され, 森林は後退する。ところが Sub-Zone 6 に入って, もら一度森林の復活 がみられ, 農耕地は廃棄される。ようやく地表下 $15 \mathrm{~cm}$ の Sub-Zone 7 に至って, 牧 畜に中心を拈く農業活動が再開され，現在の植物景観を形成したのである。

以上の如く, 北部地域の Ayr 州に扔いては, 今までに述べてきた南部諸地域とは, かなり様相を異にしていることがわかる。すなわち，南部地域に拈いては， B. C. 3,000 年以降, 新石器時代人による植生破壞がかなりの程度進んでいたのに対し, 北部のAyr 州では, B.C. 1, 875年以前は, 若干の人類居住の痕跡はみられるものの，植生破壞は湴 とえど行なわれていなかった。A.D.450年頃に始まった広範な植生破壞の段階も，その 130年後には中断し, 再び森林が回復している。こうした森林の復活と農耕地の廃楽は, その後数回繰り返されている。これはまさに，自然条件が緟しく，人類の側の力が微弱 な段階に拉ける，辺境地方の特色める植生と人類とのかかわりあいを示すものである。 こうした現象は，より北部の Perth 州の分析結果にも明白に現われてくる。

(6) Perth 州 Flanders Moss (J. Turner, 1965)

Flanders Moss の分析結果（第 5 図一(9)）においては, 地表下 $165 \mathrm{~cm} の \mathrm{C}^{14}$ 年代 B. C. 760 年以前の地層からは，人類による植生破壞の痕跡をみることが出来ない。この ことは，いまだこの周辺では花粉構成に変化を起こすよらな人類の植生破猿が行なわれ ていなかったことを示すと考学られる。C 14 年代 B. C. 760 年以降, C14 年代 A. D. 220 年までの間は, Gramineae, Plantago, Pteridium の出現率が $20 \%$ 前後に達し, 一時的 な植生破壞の段階を示している。地表下 82 ～ $75 \mathrm{~cm}$ の間では, Gramineae の出現率が $100 \%$ 近くに達し，ほぼ広範な植生破壞の段階に近ついたことがわかる。ところが地表 下 $75 \mathrm{~cm}$ 以上になると, 再び Gramineae, Plantago などの出現率は減少し, 代わって Betula, Quercus の花粉が增加している。したがって, ここにおいいても，A. D. 200 年前 後を境として, 農耕地の放棄が行なわれ, 森林の回復がみられたことがわかる。完全な る植生破壞の段階は, 地表下 $15 \mathrm{~cm}$ 付近の Gramineae, Plantago の花粉出現率が増加 するところから始まる。

31) Turner, J. (1965) : ibid. 
この他, 北部地域には, F. Oldfield (1963) の Red Tarn Moss の分析結果, W. Pennington (1965) の Blelham Tarn の分析結果（第 5 困一(7)）などがある。いずれ も，これまで述べてきた Ayr 州・Perth 州などの辺境地方の分析結果と同様の傾向を 示す。

\section{I-（3） 各地域の分析結果の比較}

さて, 以上述べてきたイギリスの各地域に括ける花粉分析結果を, 植生破壞の程度と 時期に注目して，円形の花粉ダイアグラムで緯度毎に配列すると第 5 図の如くになる。 この図を中心に，新石器時代・青銅器時代・鉄器時代にわたる人類の植生破壞の地域性 を考察してみよう。

新石器時代初期においては，人類は家畜を森林内に放牧し，若干の原始的農業を行な っていた。彼らは定住することなく移動していた。この時代においては，植生は一時的 に破壤されたものの，人類の居住地の放棄に伴って，再び森林が回復した。こらした一 時的な植生破壊は, 南部の Old Buckenhammer では, B. C. 3,000年頃から, Shippea Hill 遺跡では B. C. 3, 500年頃から，すでに起っていた。ところが，北部の Bloak Moss では B.C.1,000年頃, Flanders Moss では B.C.760 年頃になって, ようやく一時的な 植生破壊の痕跡が, 花粉ダイアグラムに現われてきた。この時代, 南部の石灰岩地帯で は，広範な植生破壞の段階が現出していた。

このよらに，一時的な植生破壞の開始期は，ここに上げた花粉ダイアグラムから考察 した場合には, 北部と南部地域では, 2,000 年以上の差がある。南部の海岸地帯では, すでに遺跡周辺の植生がかなり破壊されていた時代に，北部地域においては，らっそう と森林が繁茂していたことが想像されるのである。これは南部ほど時代の古い新石器時 代遺跡があり, 遺跡の数も多いのに対し, 北部にいくに従い, 時代が新しくなり, 遺跡 数も少なくなるという考古学的事実ともらまく対応する。したがって, 農耕伝播による 人為的な植生破壊を復原した結果からみた場合にも, イギリスの新石器文化は南部の海 岸地帯に伝わり, 次第に内陸部, 北部へと伝播, 拡大していったことが推察されるので ある。

青銅器時代に抮いても, 南部と北部の植生破壤の違いは明白で少る。ただ新石器時代 から青銅器時代への変化は，人類の植生破壞にそれほど大さな差はもたらさなかった。

32) Oldfield, F. (1963): "Pollen analysis and man's role in the ecological history of the south east Lake District" Geografiska Annaler, vol. 45.

33) Pennington, W. (1965): "The interpretation of some post-glacial vegetational diversities at different Lake Disrict sites" Proceedings of Roy. Soc. London, vol. 161. 
これに対し, 青銅器時代から鉄器時代への移行は, 人類と植生とのかかわりあいに, 劇 的な变化をもたらした。
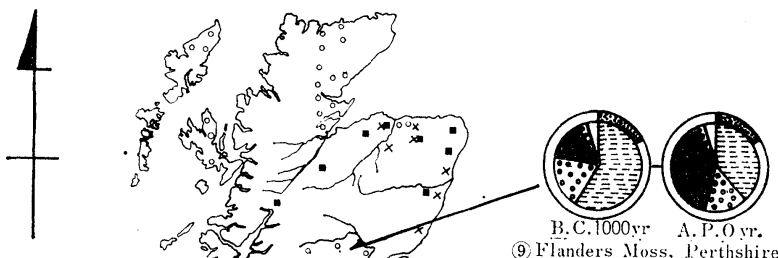

(9) Flanders Moss, P'erthshire (J.'Turner. 1965)

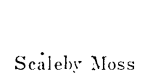

B.C.2975 134 y
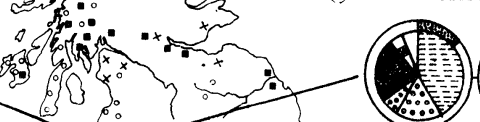

B.C.2000yr. A.1). O vr:

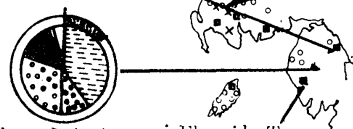

(7) Blelham Tarn, Lake District Whenside Tarn (II. Penningt on 1965 ) B.C.3010 $300 \mathrm{yr}$,

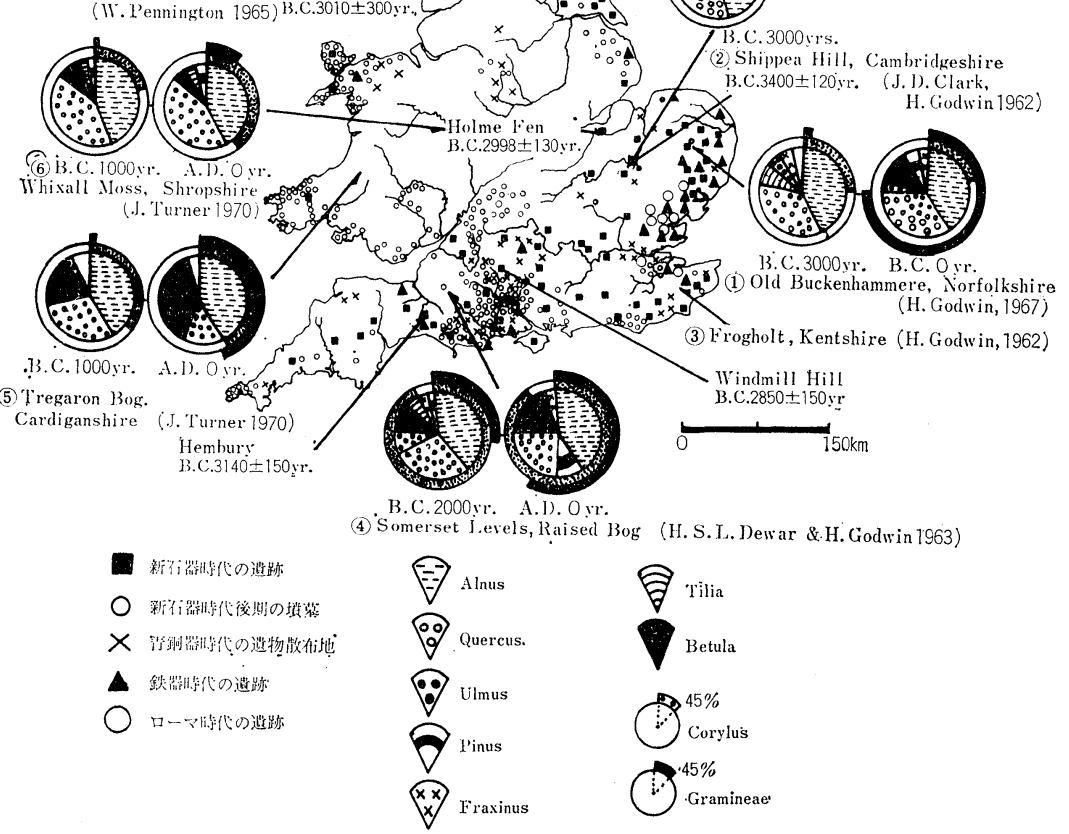

第 5 図 イギリスの新石器時代遺跡の分布と植生

遺跡分布は V.G. Childe (1950)，G.Daniel (1950)，S. Piggott (1965) にもとづき示した。 遺跡分布は正確をさしがたいが，大略の傾向は把握できるものと考える。

新石器時代農耕遺跡の C14 年代は, J. G. D. Clark, \& H. Godwin (1962), J. G. D. 'Clark (1965) による。 
鉄器時代に入ると, 南部諸地域においては, 広範な植生破壊の段階が一般化してくる。 すでに Frogholt のように，青銅器時代に広範な植生破壞の段階に達したところもあっ たが，この時代になると Old Buckenhammere や Tregaron Bog においても，急速な 森林破壊が引き起こされてくる。この鉄器文化の導入による広範な植生破壊の現出は, 南部においては，B.C. 400 年前後のことであった。そうして，この人類による急速な植 生破壞は, 単に鉄器の導入といら以外に, 牧畜を中心とする生産様式の発展に伴ら家畜 による植生破壊が大きな役割を果たしていた。

一方, 北部地域に拈いては, この鉄器文化の導入による広範な植生破壞は，A. D. 400 年前後になって,ようやく出現する。これは南部諸地域に比して, 約1,000年遅れている。 しかも, Bloak Mossや Flanders Moss に怙いてみられたように, 一旦引き起こされ た広範な植生破壞も, その後, 再び森林が回復し, 農耕活動の放棄が認められるのであ る。北部諸地域に扣いては, 農耕地の拡大と後退といら, 辺境地方に打ける自然と人類 との闘いの様が，植物景観の変遷から，明白に読み取ることが出来たのであった。

現在の植物景観を形づくった完全なる植生破壞の段階は, 現在より数百年前にはじま った。イギリス全域に拈いて，時代的にはそれほど大きな差はない。しかし，南部の石 灰岩地帯の Frogholt に执いては, すでにB.C.680年頃から, 現植生とほぼ類似した植 物景観が形成されていた。

以上の如く, イギリスにおいては, 新石器文化・鈴器文化などの, この地域の生態系 を変化させるだけの新しい文化の導入は, 南部地域から始まり, 次第に北部へと伝播, 拡大していったことが，人類による植生破壞の地域的比較から，明らかになった。そう して文化伝播による植生破壊の様式にも，南部と北部とでは，大きく異なることがわか った。

$$
\text { II 日 本 }
$$
日本にあっては, 小牧実繁 (1937) が先史・歴史地理学の主要課題として, 植物景観
復原を取り上げてから久しい年月が過ぎ去った。その後, 藤岡謙二郎 $(1955)$, 谷岡 武雄（1963）らによっても, 先史・歴史地理学における植物景観変遷の研究の重要性は 指摘されてき。こうした中にあって, 千葉徳爾 $(1950 \cdot 70)$ は歴史時代に括ける自然と

34）小牧実繁 (1937):『先史地理学研究』.

35）藤岡謙二郎 (1955)：『先史地域及び都市域の研究』柳原書店.

36）谷岡武雄 (1963) : 『平野の地理』古今書院.

37）千葉徳爾 (1950):『ハダ山の研究』古今書院, （1970）：近世中末期美濃地方の丘陵地に拉 ける林野の荒廃について, 臮知大学総合郷土研究所紀要 vol. 15. 
人類とのかかわりあい，なかんずく人類活動による自然の生態系の破壊に注目し，人類 による植生破壊の歴史を跡づけ，そのフィールドは東アジア $(1955 \cdot 72)$ にも及んでい る。花粉分析などの植物景観復原の技術導入以前に执いて，かかる研究がなされたこと は高く評価されねばならない。保柳㓐美 (1943) の北支・蒙古に抢ける研究は, 人類の 森林伐採と気候変化・土壤侵蝕との関連を論じ，その提起された問題は，数十年後の今 日に执いてもな特，重要な研究課題として生きている。

また湿潤熱帯においては，アランアランの景観を純粋な自然景観ではなく，人類の営 力が存在することを必要条件とする文化景観であると述べた能登志雄 (1952) の研究が

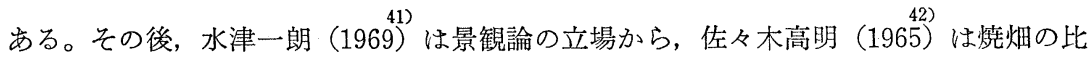
較歴史地理の立場から，ヨーロッパに抢ける人類の植生破壊の研究例を紹介した。ま た日下雅義（1972）は，「人間による土地環境改変」の一つの研究分野として，人類に よる植生破壞を取り上げている。そうして西村嘉助（1969）は，かかる人類の植生破壊 の研究を, 応用地理学の主要な研究分野として位置づけた。こうした研究の充実を背景 として, 近年ようやく花粉分析法による植物景観復原の研究が，実際のフィールドにお いてもなされるようになった。矢の先駆をなしたのは千田稔（1971）である。筆者の立 場もこれら一連の諸先学の研究業績を背景としている。

さて，ここで筆者が問題とするところは，日本の稻作はいったい日本列島のどの部分 に最初に伝播し，そらして拡大していったか。あるいは稲作はいかなる植物景観の下に 導入され，その導入の結果，従前の植生をいかに改変したかを，イギリスとの比較にお いて論ずることである。

\section{II-（1） 弥生時代遺跡の分布}

日本の稲作は，いったい日本列島のどの部分に伝播し，そうして桩大していったもの なのか。この問題に関しては，古くから考古学・民俗学などによって諭じられてきた。 第 7 図は, これまでの発掘報告書ないしは遺跡分布図から作成した主要な弥生遗跡の分 布図である。この図から明らかなように，分布中心は北九州・瀬戸内・近畿地方であり，

38）千葉徳爾 (1955)：東アジアの人為的荒廃林地に関する 予察報告, 東北地理, vol. 8-2. (1972)：中国中南部の土壌侵蝕と農耕文化, 歴史地理学紀要 vol. 15.

39）保柳睦美 (1943):『北支・蒙古の地理一乾燥アジアの地理学的諸問題一』古今書院.

40) 能登志雄 (1952): 『聚落の地理』古今書院.

41）水津一朗 (1969)：『社会集団の生活空間』大明堂.

42) 佐々木高明 (1965): 焼烟農業の研究とその課題, 人文地理, vol.17.

43）日下雅義 (1972):『平野の地形環境』古今書院.

44) 西村嘉助 (1969): 『応用地形学』大明堂.

45）千田稔 (1971): 奈良盆地弥生式遺跡に挌ける花粉学的考察, 地理学評論, vol. 44. 
関東・北陸・東北地方にいくにつれ，漸次少なくなっていることがわかる。また遺跡の 大半は, 海岸部の沖積平野, ないしは内陸盆地の沖積平野に集中している。

近年の古代米の研究（佐藤，1971）によれば, 弥生時代前期の粐痕は, 王倒的に西日 本に多く, 弥生時代中期から後期に向からにつれ, 次第に関東一東北地方に出土例が増

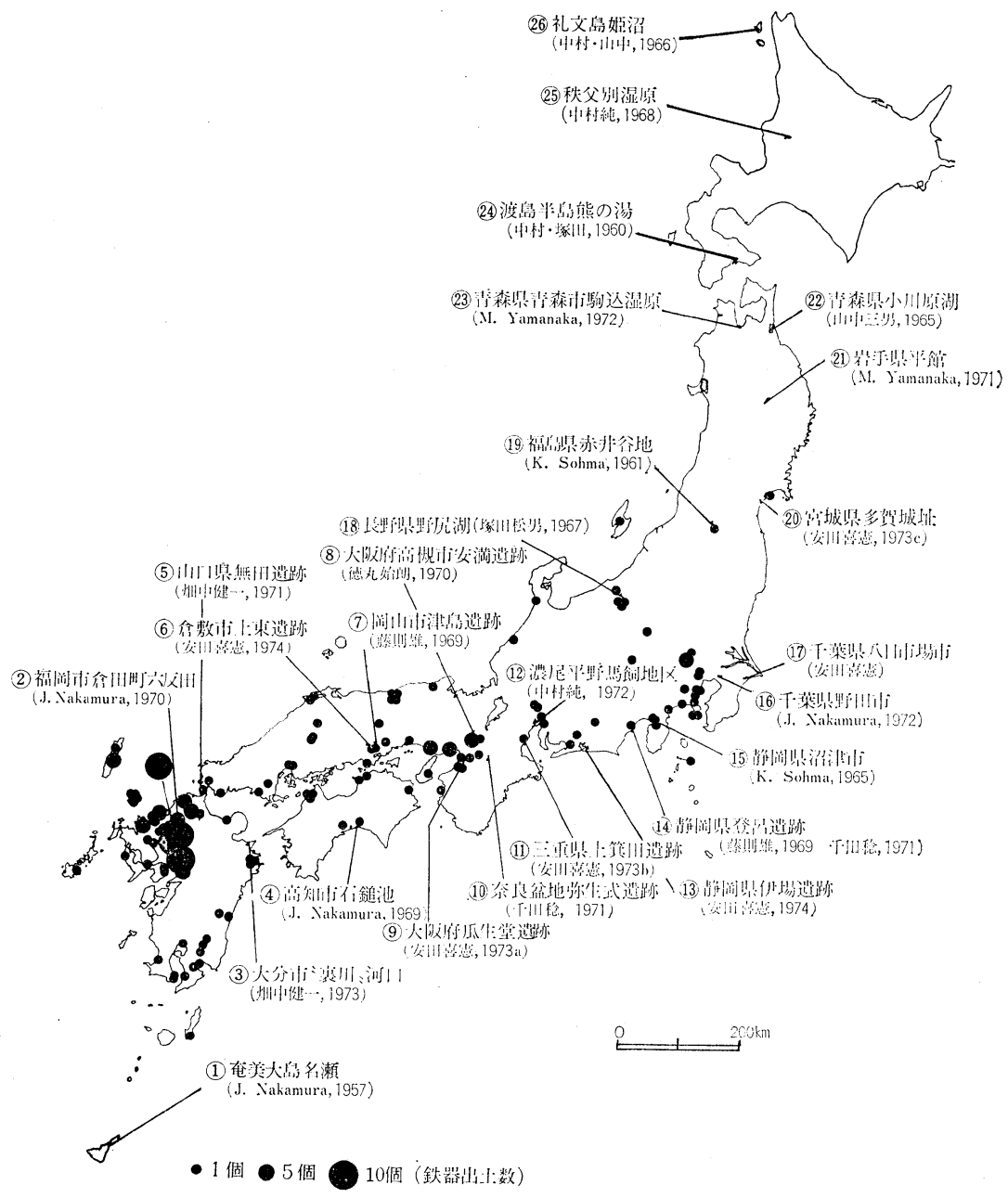

第 6 図 弥生時代の鉄器出土地点と花粉分析試料採集地点 鉄器出土地と数は藤田・川越（1970）による。

46）佐藤敏也 (1971):『日本の古代米』雄山閣. 
加することが明らかになっている。このよらに弥生時代の遺跡の分布並びに古代米の研 究から, 稲作は西日本のどこかで導入, 発展させられ, 次第に関東・東北地方へと拡大 していったことが考えられる。

それでは, こうした稲作の伝播と拡大の過程は, 植物景観の变遷からみた場合, いか なることが言えるであろらか。すでに述べた如く, 人類の農耕活動は, 遺跡周辺の植生 を改変する一つの大きな要因をなしていた。弥生時代における鉄器の導入は，いまだ一 般化はされていなっかとは言光，人類の森林破壊をより容易にしたものと思われる。 第 6 図には，これまでに明らかになった弥生時代の 鉄器出土地を示す（藤田・川越, 1970)。この図から明らかなように, 鉄器の出土地は圧倒的に西日本, それも九州に多 い。このように早くから稲作が伝播し, 多くの弥生遺跡が分布し, かつ高い農業の発展 段階に達していた西日本と, 遺跡数も少なく, 稲作の導入時期も遅い関東・東北地方と では, 人類による植生破壞の時期, 並びに植生破壊の程度にも大きな違いがあったもの と考觉られる。

したがって, 日本列島の各地域に稲作が導入された当時の原植生を復原し, その原植 生が稲作の導入によって, いつ頃，いかに改変されたかを論じうるならば，稲作の伝播 と拡大の過程並びにその生態学的意味を，より明白に論じうるはずである。そこでこ うした観点に立って, 日本各地域における花粉分析のデーターを比較検討してみる。そ の際, 選定した花粉分析のデーターは, いずれも弥生時代以来, 人類の居住地の中心と なってきた沖積平野周辺に拉ける分析結果である。従来の日本の花粉分析のデーター は，洪積世以前のものか，人跡未踏の高層湿原での分析結果が大半であり，しかも人類 による植生破壊を論じうるに足る細かな分析結果はわずかである。ここで取り上げるの は，既存の分析結果と，筆者が新たに行なった分析結果 4 地点のデーターである。

\section{II-(2) 各地域の分析結果}

(1)福岡市倉田町六反田 (J. Nakamura, 1970)

北九州には板付遺跡を始め, 多くの弥生時代遺跡が分布する。ここで取り上げるのは, 遠賀川の支流，西川の形成した沖積平野から採集した資料の分析結果である。この地域 の現植生は, Pinus densifiora, Quercus serrata, Cyclobalanopsis glauca, Myrica rubra などからなっている。周辺には弥生時代遺跡が多く分布する。分析は $\mathrm{KOH}$ ーアセトリ

47）藤田等・川越哲志 (1970)：「弥生時代鉄器出土地地名表」たたら研究会編『日本製鉄史論』 所收.

48) Nakamura, J. (1970): "Palynological evidence for Recent destruction of natural vegetation III" Annual Rep. of J. I. B. P. 
シス $-\mathrm{ZnCl}_{2}$ 法で行なわれている。この花粉ダイアグラムにおいては, 人類の森林破壊 に関して 3 回の注目すべきェポックがみられる。その一つは, 地表下 $250 \mathrm{~cm}$ の層準に おいてみられる。これまで50\%以上の出現率をもっていた Shiia の花粉が，この層準に おいて10\%前後に急減するのである。これに反し, Cyclobalanopsis, Artemisia, Gleiche$n l a$ などの花粉が急増する。さらに $1 \mathrm{~g}$ 単位あたりの試料に含まれる木本花粉の絶対数 を示す絶対花粉も，30,000個/g から5,000個/g に急減する。すでに地表下 $300 \mathrm{~cm}$ の地 点からは, Hordeum と予想される栽培種の Gramineae の花粉が出現している。したが って, この急激な Shiia の減少は, 農耕活動による人為的な植生破壤の結果である可能 性が強い。

稲作を伴う人類の活動によって引き起されたとみられる植生变化は, 地表下 $200 \mathrm{~cm}$ の層準にみられる。植生はこの付近を境として, Shiia, Cyclobalanopsis の花粉が急減し, これに代わって, Quercus, Myrica の花粉が増加する。これは農耕活動を伴った人類に よる植生破壞の結果, Shiia, Cyclobalanopsis の森林が, Quercus, Myricaを中心とする 二次林へ転化したことを示す。

第 3 のエポックは, 地表下 $110 \mathrm{~cm}$ の層準に拈いてみとめられる。すなわち, 地表下 $110 \mathrm{~cm}$ の層準を境として, Pinus の花粉が次第に増加を始め, 現地表面付近に拈いて, 最大の出現率に達する。同じく Gramineae, Artemisia の花粉が急増する。そうして農 耕活動によって人為的に形成された荒地に生育する Fagopyrum が, 出現率を增大させ る。これまで優勢であった Quercus, Myrica, Shiia, Cyclobalanopsis などの木本花粉が 減少する。絶対花粉もこの層準で急減する。これは明らかに人類の植生破壊の様式に, 大きな変化があったことを示している。それは新しい農業技術の導入，人口の増大など によって，人類の植生に対する干渉の程度がより強くなったことを示している。

この Nakamura (1970) の明らかにした人類による植生破壞を, イギリスの Turner の三段階説にあてはめてみると, 地表下 $300 \sim 110 \mathrm{~cm}$ の Shiia, Cyclobalanopsis の森林 の破壤は, その間に森林の回復がみられ, Gramineae の出現率が 20〜 $50 \%$ であること から, 一時的植生破壊の段階とみられる。そののら, 地表下 $110 \mathrm{~cm}$ を境とするQuercus, Myrica の森林をも含めた急速な植生破壊は, 広範な植生破壊の段階に対応する。現景 観を形造った最後の完全な植生破壞の段階は明白には現われていないが，地表下 $30 \mathrm{~cm}$ 前後のPinus を中心とする二次林の形成と対応するものと考えられる。

(2)岡山県津島遺跡（藤則雄, 1969)

49) 藤則雄 (1969): 岡山県津島遺跡の花粉学的研究, 考古学研究, vol. 62. 
津島遺跡は, 岡山県泉町の旭川の形成する沖積平野にある。旧水田土壤検出のため, 花粉分析が行なわれた。分析方法は $\mathrm{HF}$-アセトリシス-KOH 法である。

その分析結果に上れば, 弥生時代前期には, 遺跡周辺には, Quercus, Pinus, Cryptomeria, Zelkova, Castanea, Alnus などが生育していた。特に Quercus とPinus が高い 出現率を示している。弥生時代中期になると, Cryptomeria, Pinus が優先種となる。特 にCryptomeria は高い出現率を示す。さらに注目すべきは，こうした出現花粉の中で， 栽培種とされる $40 \mu$ 以上の Gramineae の花粉が最も高い出現率を示すことである。こ の他草本類, 羊歯類には, Persicaria, Osmunda, Myriophyllum などの低湿地に生育す る植物の花粉, 胞子も出現している。

このことから，津島遺跡においては，稻作導入当時の植生は，Quercus，Pinus を中 心とする森林が広がって拈り, その後, 弥生時代中期になって, Cryptomeria を中心と する菻林に変ったことが知られる。そうして，40 $\mu$ 以上の栽培種と思われる Gramineae の花粉が, 全出現花粉中最も高い出現率を示すことから, 遺跡周辺の植生はかなりの程 度破壞され，水田や低湿地が広がっていたことが知られる。

(3)岡山県上東遺跡（安田喜憲，1974）

岡山県における弥生時代後期の代表的遺跡として, 倉敷市上東にある上東遺跡を取り 上げる。遺跡は海抜 $1 \mathrm{~m}$ 前後の足守川の沖積平野に立地している。遺跡の立地する沖積 平野の南部之北部には, 海抜 80 100m 前後の丘陵が連なっている。この地域の現植生 はPinus densifiora, Quercus serrata, Cryptomeria japonica などからなっている。

弥生時代後期の人々がこの地に居住を開始する以前の堆積層の分析結果に扔いて，最 も高い出現率を示すのは Cyclobalanopsis であり，その出現率は $30 \%$ 前後に達する。続 いて Quercus, Pinus, Abies, Tsuga, Shiia or Castanea, Celtis などが比較的高い出現 率を示す。草本花粉・胞子においては，Polypodiaceae が 5 10\% 前後の出現率を示す 他は, 顕著な出現は認められない。それは $\Sigma \mathrm{AP} と \Sigma \mathrm{NAP}$ の出現比率にも明白に示さ れている。ところが, 弥生時代後期のピットの分析結果に执いては, これまで優占して いた Cyclobalanopsis が 30\% 前後から $7 \%$ 前後にまで出現率を低下させる。それ以外の 木本花粉も同様に急減する。一方, 草本花粉・胞子においては, これまで顕著に認めら れなかった $40 \mu$ 以上の栽培種と想定される Gramineae, Rumex, Chenopodiaceae, Caryophyllaceae などが一斉に出現してくる。弥生時代後期のピットに拈けるこうした草 本花粉・胞子の増加は， $\Sigma \mathrm{AP}$ と $\Sigma \mathrm{NAP}$ の出現比率のグラフからも明白に読みとれる。

50）安田喜憲 (1974)：弥生時代遺跡の花粉学的研究, 立命館文学（投稿中）. 
このことは, 弥生時代後期の人々の居住の開始に伴って, これまでこの周辺に生育して いた Cyclobalanopsis を中心とする森林が切り払われ，上記の草本類・羊雬類が生育す るよらな荒地が形成されたものとみることが出来よう。

(4)高知県石鎚池 (J. Nakamura, 1969)

石鎚池は高知市の東方に位置し，現浜堤背後の潟湖のうずみ残しと考えられる。現在， この地域の沖積平野は水田に利用され, 丘陵部には, Quercus serrata, Cyclobalanopsis glauca, Shiia sieboldii, Myrica rubra などが生育している。前面の海岸の浜堤上には 弥生時代の遺跡が立地する。花粉分析の試料はヒーラー型ボーラーで池底から採取され

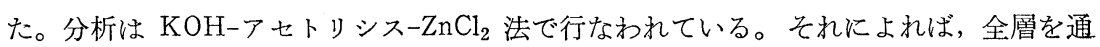
して Shiia, Cyclobalanopsis, Myrica を中心とする常緑広葉樹林が優占する。花粉ダイ アグラムの最下部は B. P. 4,000 4, 500 年頃と考えられている。この石䤼池から $6 \mathrm{~km}$ 離れた地点には, 粐痕を出土寸る弥生時代の遺跡がある。しかるに, この石鍠池の花粉 ダイアグラムに拈いて, 栽培作物の痕跡が認められるのは, ようやく地表下 $60 \sim 70 \mathrm{~cm}$ 前後になってからである。さらに二次林としての Quercus や草本花粉の Artemisia, Gramineae などが増加し, APF が減少することより，人類の森林破壞の影響が認めら れるのは, ようやく地表下 $40 \mathrm{~cm}$ 前後の層準になってからである。分析者の示した泥土 の堆積速度からみても, この地域において農耕を伴ら広範な森林破壤が引き起されるの は, B. P. 1,000年を遡らないと考えられる。

(5)大阪府高梘市安満遺跡 (徳丸始朗, 1970)

安満遺跡の分析結果によると, 弥生時代第 1 様式に执いては, 木本花粉が Salix $8 \%$, Quercus 6.5\%, Cryptomeria 3\%と少ない。これに対し草本類, 羊歯類は, Gramineae $29.5 \%$, Polypodiaceae $44.5 \%$ と高い出現率を示す。このように全出現花粉数の中で, 草本類, 羊歯類に比して, 木本花粉の出現数が非常に少ない。このことから, 弥生時代 において, 安満遺跡周辺の丘陵はかなり荒れており, 陽生草本類が山肌を特括い, 安定し た森林が形成されていたとは考えがたいと，分析者が指摘していることは注目される。 ただ花粉の同定に 2 ・3 の問題があり,データの信頼性が心配される。6大阪 府瓜生堂遺跡 (安田喜憲, 1973 a)

51) Nakamura, J. (1969): "Palynological evidence for Recent destruction of natural vegetation II" Annual Rep. of J.I. B. P.

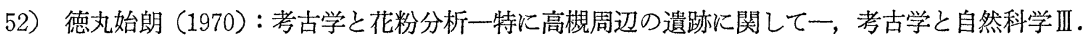

53）安田喜憲 (1973a)：「瓜生堂遺跡の泥土の花粉分析」, 瓜生堂遺跡調査会『瓜生堂遺跡 II』所 収. 
瓜生堂遺跡は大阪府東大阪市西若江にある。遺跡は生駒山地の西麓, 旧大和川の形成 した沖積平野の地表下 $4 \mathrm{~m}$ 前後に埋没している。この遺跡の泥土の花粉分析結果の特色 は, 弥生時代の人々がこの地域に居住を開始する以前の遺跡周辺の植生と, 弥生時代中 期の人々が居住した当時の植生, ならびに弥生時代中期の人々が居住を放棄してからの 遺跡周辺の植生には，大きな違いが認められることである。すなわち，人々が居住を開 始する以前には, 遺跡周辺の沖積平野の微高地や丘陵部には, Cyclobalanopsis, Shiia を 中心とする，いわゆる常緑広葉樹林が，らっそうと繁茂し，これと共に，Abies，Tsuga， Cryptomeria, Pinus などの針葉樹や，Quercus などの落葉広葉樹が若干生育していた。 そうして，沖積平野の低湿地には，ヨシなどの野生の Gramineae が 生育していた。 Gramineae の粒径分析の結果, 当時は, この地域周辺では, いまだ人類による農耕活 動の痕跡は認められなかった。

ところが，その後洪水が起こり，遺跡周辺の沖積平野には，灰白色の砂礫層からなる 微高地が形成された。弥生時代中期の人々は，この微高地上に居住を開始した。この弥 生時代中期の人々が生活した 当時の遺跡周辺の植生は, Gramineae, Polypodiaceae, Lycopodiaceae などが圧倒的に多く出現するオープンな景観の草原であった。この植生 を変化させた原因として, 灰白色の砂礫層を堆積した洪水の影響と, 弥生時代人の農耕 活動を伴ら森林破壞が考えられた。イネ科花粉あるいは他の草本花粉の出現率からみ て, 弥生時代中期の人々が居住した当時の, 遺跡周辺の植生は, イギリスの広範な植生 破壊の段階に対応すると考えられる。

弥生時代中期の遺物包含層を覆う粘土層に入ると, 木本花粉の出現率が増加し, こ れまで高い出現率を示していた Gramineae, Polypodiaceae, Lycopodiaceae が激減し た。こうした事実は, 居住地の放棄に伴い, 再び遺跡周辺に森林が回復してきたこと を示すとみてよい。しかし，この場合注目されることは，居住地が放棄され，弥生時 代の人々が移動した結果, 居住地周辺に回復した森林は, 弥生時代の人々が居住する以 前のうっそうとした Cyclobalanopsis, Shiia を中心とする常緑広葉樹林とはいささか性 格を異にしていることである。すなわち，弥生時代中期の 遺物包含層を覆ら粘土層に おいては, Cyclobalanopsis, Shiia or Castanea と共に, Cryptomeria, Pinus, Quercus などが増加してくるのである。こうした弥生時代中期の遺跡放棄の後に, 新たに出現し てくる Pinus, Cryptomeria, Quercus は, いずれも二次林的性格の強いものである。し たがって, 弥生時代人の移動と 居住地の放棄に伴い遺跡周辺に回復してきた森林は, Cyclobalanopsis, Shiia の森林に, Cryptomeria, Pinus, Castanea, Quercus などの二次 
林的性格の強い森林が混生したものであったと言える。

(7)奈良盆地弥生式遺跡（千田稔，1971）

奈良盆地の諸遺跡における花粉分析の結果，木本花粉ではQuercus, Pinus, Cryptomeria が優先し, Quercus は植物遺体から Quercus serrata, Quercus glauca などであろら と推定されている。草本類では Gramineae が優先する。また二次植生としてのP inus を30\%以上も出現する遺跡があることから，遺跡によっては人為的に周辺の植生がかな り改変を受けていたことが想定される。

8)三重県上箕田遺跡 (安田喜憲, 1973 b)

上箕田遺跡は三重県鈴鹿市上箕田にある。現海岸線から $2 \mathrm{~km}$ 内陸, 海抜 $5 \mathrm{~m}$ の鈴鹿 川の沖積平野に立地する。筆者は第 3 次の発掘に際して現地を訪れ, トレンチの断面か ら花粉分析用の泥土の採取を行なった。分析法は $\mathrm{KOH}$ ーアセトリシスー $\mathrm{ZnCl}_{2}$ 法を用い, 木本花粉 160 個以上を同定した。その結果, 弥生時代前期〜中期初頭の遺物包含層では, Cyclobalanopsis が最も優先し, 続いて, Cryptomeria, Quercus, Shiia, Pinus が高い出 現率を示す。草本類では, $40 \mu$ 以上の Gramineae が高い出現率を示し，続いて Chenopodiaceae, Cyperaceae, Artemisia, Umbelliferae などが出現する。

さらに弥生時代後期に入ると，木本花粉ではこれまで優先していた Cyclobalanopsis ・ Shiia が減少し, 代わって Cryptomeria, Pinus, Quercus が増加する。草本類では, 40 $\mu$ 以上の栽培種と思われる Gramineae の出現率に比して, $40 \mu$ 以下の野生種と思われ る Gramineae がむしろ高い出現率を示す。弥生時代前期〜中期初頭にかけての Cyclobalanopsis・Shiia を中心とした森林が，弥生時代後期になると Cryptomeria ・ Pinus を 中心とする森林に変化するのは, 気候変化とともに, こうした人類の農耕活動を伴った 森林伐採が，一つの大きな要因をなしていたと考觉られる。Gramineae の出現率から みて, 上箕田遺跡における植生破壊の段階はイギリスの広範な植生破壞の段階に比定さ れる。しかし，その景観は $\sum A P と \sum N A P$ の出現比率からみて，大阪の瓜生堂遺跡や 安満遺跡周辺の如く広範な荒地が広がる景観よりは, やや森林の多いものであったこと が考学られる。

(9)静岡県伊場遺跡（安田喜憲, 1974)

伊場遺跡は浜松市西伊場にある。遗跡は天竜川下流の沖積平野に発達する数列の砂州

54）千田稔 (1971)：前掲.

55）安田喜憲（1973b）：三重県上箕田遺跡に抢ける弥生時代の自然環境の変遷と人類, 人文地理 vol. 25.

56）安田喜憲 (1974)：前揭. 
の内, 内陸側の砂州上に立地する。遺跡の立地する海抜高度は $2 \mathrm{~m}$ 前後である。遺跡の 背後には, 海拔 $30 \mathrm{~m}$ 前後の三方原台地が広がっている。沖積平野は水田に利用され，丘 陵部には Pinus densifiora, Cryptomeria'japonica, Quercus phillyraeoides などが生育し ている。遺跡の主体は古墳時代〜歴史時代にかけてであるが，弥生時代後期の遺物包含 層も認められる。花粉分析の結果, 弥生時代後期の人々が居住を開始する以前には, こ の地域の沖積平野には, Typhaceae, 野生の Gramineae, Polypodiaceae が生育し, 丘 陵部には Cyclobalanopsis を中心とし, これに Quercus, Shiia or Castanea, Celtis など を伴う森林がうっそうと繁茂していたと考えられた。ところが，弥生時代後期の遺物包 含層に入ると，草本花粉に拈いてこれまで高い出現率を示していた Typhaceae が激減 し, かわって $40 \mu$ 以上の栽培種と想定される Gramineae が增加する。このことは, 弥 生時代後期の人々の沖積平野への進出により，これまでの Typhaceae を生育させるよ らな低湿地が，稲作の導入によって次第に減少していったものとみることが出来る。し かしながら，木本花粉に招いては，弥生時代後期の遺物包含層に入っても，Cyclobalanopsis, Quercus, Shiia or Castanea などが高い出現率を示し，これまでみてきた西日 本の弥生時代遗跡とはいささか異なった様相を呈している。このことは, 弥生時代後期 には人々の居住は, 木本花粉の構成に大きな変化をもたらすだけの影響を丘陵部の森林 に与光ることがなかったとみられる。西日本の弥生時代の諸遺跡とは異なり, 遺跡背後 の丘陵部には Cyclobalanopsis, Quercus, Shiia or Castanea, Celtis の森林がうっそうと 繁茂していたとみられる。

(10静岡県登呂遺跡 (藤則雄, 1969)

静岡県安倍川の沖積平野に立地する登呂遣跡の花粉分析は, 弥生時代後期の水田土壤 之古墳時代の土壌について行なわれている。それによれば，弥生時代後期の文化層にお いては, 植生は Cryptomeria, Quercus, Abies, Pinus などが生育して抢り, 特にCryptomeria と Quercus が優先種であった。古墳時代に入っても, Cryptomeria, Quercus が優先し，その他に Castanea, Fagus が新たに出現する。そうして Pinus, Tsugaが増 加する。

こうした花粉分析から推定される遺跡周辺の植生は, 登呂遣跡から出土する木器, あ るいは田杭の多くが Cryptomeria から出来ていることからも裏付けされる。木工具, 建 築材などにスギ材が多く利用されているといらことは, 人為的選択の他に, むしろ周辺 の植生を反映したものとみなす方が妥当であろう。

57）藤則雄 (1969)：前掲. 
東海地方にはこの他, 山木遺跡（後藤守一編, 1962) がある。この山木遺跡において も，利用材の中心はスギであることが報告されている。弥生時代の登呂遺跡の人々にと って, 最も手軽にかつ容易に利用出来たのはスギであったとみることが出来る。遺跡周 辺の Cryptomeria を中心とする森林は, こらした弥生時代の人々によって, 建築材, 土 木材，木工具の材料として利用されたのである。

以上みてきた各地の分析結果は, いずれも現在の植生分布からみた場合, 照葉樹林帯 に属するものであった。これに対し, これから述べる分析結果は, いずれも現在では落 葉広葉樹林帯に属する地域のものである。

(11)野尻湖湖底泥（塚田松雄, 1967)

野尻湖は海抜高度 $654 \mathrm{~m}$, 面積 340 ha の湖で, 中部山岳地帯では低地にあたり, 湖岸 には縄文時代以降の遺跡が分布する。この地域の現在の植生は, Pinus densifiora ・Cryptomeria japonica・Quercus serrata を中心とする二次林が卓越する。平坦部にはイネ・ ムギが，丘陵地にはソバ・リンゴが裁培されている。花粉分析に使用された試料は湖底 から $2.5 \mathrm{~m}$ の長さで採集された有機質粘土である。その分析結果によれば，花粉ダイア グラムは下部から L・RI・RII・RIII $\cdot \mathrm{RIII}_{\mathrm{b}}$ 帯に区分される。

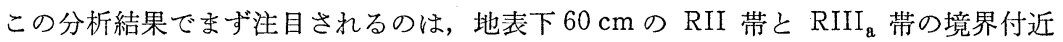
で，栽培種と想定される Gramineae の花粉が検出されていることである。その出現時 期は， $\mathrm{C}^{14}$ 年代と泥炭の堆積速度から，少なくとも B. P. 4, 000年以前に遡る。この時代 は縄文時代中期頃にあたり，先の Nakamura (1970) の福岡に拈ける分析結果ととも に，稲作以前に括ける農耕の存在を論ずる際に重要な事実となる。この栽培種と想定さ れる Gramineae 花粉の出現する層を境として, その上部に抢いて Ulmus, Quercus, Sciadopitys, Tilia などの花粉が減少する。したがって, この地域では B. P. 4, 000 年以 前に括いて，一時的に人類によるによる植生破壊が行なわれていた可能性がある。

地表下 $35 \mathrm{~cm}$ の層準において, Chenopodiaceae, Compositae, Gramineae などの草 本類の花粉が增加する。これに対し, Quercus, Ulmus, Fagusなどの木本花粉が減少す る。 $\mathrm{C}^{14}$ 年代測定と泥炭の堆積速度から, この時代は B. P. 2, 000年頃と考えられる。時 代的にみて，この層で Gramineae の花粉が急増することは，括とらく弥生文化の導入 により, 新たな植生破壞が引き起こされたものとみることが出来る。絶対花粉もこの層 を境として, 11, 740/ $\mathrm{cm}^{2} /$ 年から $5,170 / \mathrm{cm}^{2} /$ 年に隇少している。

58）塚田松男（1967）：過去一万二千年間：日本の植生変遷史 I， Botanical Magazine, vol. 80.

59) Nakamura, J. (1970) : 前掲. 
その後, C 14 B.P.1, 530年の值が得られた層準において, 劇的な植生変化がみられる。 これまで優先種であった Fagus, Quercus, Sciadopitys, Ulmus, Zelkova, Tilia な゙の 木本花粉が急減し，注とんど数\%の出現率を示すにとどする。これに対し Chenopodiaceae, Compositae, Gramineae などの草本類が急増し, 二次林的性格が強いPinus • Cryptomeria の花粉が同じく急增する。これは明らかに，古墳時代の入々によって広範 な植生破壇が引き起こされたことを示すものである。絶対花粉の変化から，この古墳時 代に打ける植生破壊は弥生時代以前の森林の72\%を破壊したとみられている。

この劇的な森林破壊の後, Pinus が低地に出現し始める。また荒地に生育するFago pyrum の出現率も增加する。さらに, ソバの花粉が B. P. 1500年, トウモロコシの花粉 も B.P.1500年まで遡ることが述べられている。

以上の如く，野尻湖においてみられた人類の森林破壤をイギリスのそれと比較すると， B. P. 4000 B. P. 1530年までの植生破壞は一時的植生破壊の段階, B. P. 1530年以降の急 速な森林破壊は広範な植生破壞の段階に比定される。完全な植生破壞は, 他の地域と同 様に，明白に区別することが出来ない。

(12)宮城県多賀城址（安田喜憲, 1973 C)

多賀城址は，宮城県多賀城市市川にある。遺跡の主体は高度30～40mの丘陵頂部にあ る。多賀城の主体をなす内城地区を方形に取り囲んで, 外郭周辺築地が存在する。外郭 周辺築地の西辺と南部の一部は, 丘陵下に発達する小開析谷の谷底平野にも及んでい る。この小支谷の沖積低地は, 砂押川の後背湿地的な堆積環境の下におかれ, 厚い泥炭 質粘土〜泥炭層が堆積している。

花粉ダイアグラムは，下部より Zone III（地表下 $230 \sim 200 \mathrm{~cm}$ ), Zone II (地表下 $200 \sim 140 \mathrm{~cm}$ ), Zone I (地表下 $140 \sim 0 \mathrm{~cm}$ ) の 3 花粉帯に区分される。人類による森林 破壞の痕跡が花粉ダイアグラムに現われるのは，Zone I に入ってからである。この Zone I に括ける植生変化は, 細かくみると 4 つの Sub-Zone に区分出来る。

多賀城址周辺の沖積低地に稲作が 導入された結果引き起こされた植生破壞は, Sub -Zone 3 (地表下 $131 \sim 100 \mathrm{~cm}$ ) に明白に現われる。それは $40 \mu$ 以上の栽培種と想定さ れる Gramineae 花粉の出現と, Alnus の急減によって示される。すなわち栽培種と想 定される Gramineae が出現する地表下 $131 \mathrm{~cm}$ の層準を境として，Alnus が $23 \%$ か 4. $5 \%$ に減少するのである。これは明らかに低湿地に生育していたハンノキ林が，稲作

60）安田喜憲 (1973c)：宮城県多賀城址の泥炭の花粉学的研究一特に古代人による森林破垻につ いて一，第四紀研究， vol. 12 . 
農業を伴う人類の沖積低地への進出によって切り開かれたことを示している。同じく河 畔に生育する Juglans が減少することも，これを裹付ける。この多賀城址周辺の沖積低 地に稲作が導入され，ハンノキ林が切り開かれた年代は，7世紀後半と考えられる。

この栽培種の Gramineae 花粉の出現に伴って, Artemisia, Cyperaceae, Umbelliferae, Gramineae (Wild type), Polypodiaceae などの 雑草類が一斉に出現率を増加さ せる。これは人類の森林破壞の結果形成された荒地に，こうした雑草群が生育を始めた ことを示す。また木本類に拈おいては Pinus, Cryptomeria, Castanea の花粉が増加し, 二次林の形成が始まったことを示している。

このように多賀城址周辺では，稲作の導入によって広範な植生破壞が引き起こされる には，7 世紀を待たねばならなかった。多賀城址の南 $9 \mathrm{~km}$ の地点には弥生時代後期の 南小泉遺跡がある。また多賀城址の東方 $4 \mathrm{~km}$ の地点には桝形囲遺跡がある。ともに粐 痕を出土して扣り，稲作農業を行なっていたことが想定されている。しかるにわずか数 $\mathrm{km}$ 離れた多賀城址周辺に，栽培種の Gramineae の花粉が出現し，農耕活動による人 類の植生破壤がみられたのは，7世紀後半に入ってからであった。このことは，弥生時 代の遗跡数が少なく, 人口密度も小さく, 農業の発展段階も低かった東北地方では, 弥 生時代人の農耕活動による森林破壞は遺跡周辺のみにとどをり, 沖積平野周辺全域にま では及ばなかったことを示している。

(13)岩手県春子谷地湿原 (山中三男, 1972)

春子谷地湿原は岩手山の南東麓にある。この湿原の泥炭の分析の結果, 花粉ダイアグ ラムに拈いて人類の森林破壊の痕跡が認められるのは，地表下 $70 \mathrm{~cm}$ の層準に敃いてで ある。この層準を境として，その上部に拈いて Cryptomeria が急減し，これに伴って Fagus も減少する。これに反し, Pinus, Quercus が増加する。このことは, 人類の森 林破壞によって Cryptomeria, Fagus などの天然林が伐採され，その跡に Pinus, Quer r us などを主とする二次林が成立したことを意味する。この人類の森林破壊が最初に認 められる層準の時代は，泥炭の堆積速度からみても B. P. 1, 000 年をさかのぼることは ないであろら。

さらにより北方の青森県駒込湿原の分析結果に拈いては, Fagus, Cryptomeria, Alnus

61）安田喜憲 (1971)：古代に抢ける仙台湾周辺の自然環境と開発, 東北地理, vol. 23.

62) Yamanaka, M. (1971): "Palynological Study of Recent Sediment in the Lowland in Aomori Prefecture”, Annual Rep. of J. I. B. P. 1971.

63）山中三男（1972）：岩手県低地带湿原の花粉分析的研究 II一春子谷地湿原一，日本生態学会誌， vol. 22. 
などが減少し，人類の森林破壊の結果形成された二次林としてのPinus が花粉ダイア グラムに拈いて増加するのは，地表下 $20 \mathrm{~cm}$ の層準になってからであり，人類の森林破 壞出現の時期はより後の時代に属することがらかがわれる。

(14)北海道秩父別湿原（中村純，1968）

秩父別湿原は石狩川本流と雨竜川とに挾まれた海拔 $40 \mathrm{~m}$ の沖積低地にある。これまで 述べてきた本州島弧以南の分析結果においては，いずれも花粉ダイアグラムの上部にお いて, 人類の森林破壊の影響を物語るPinus と農耕活動を示す Gramineae の花粉が増 加した。ところが，この秩父別湿原の分析結果では, 表層まで Pinus の增加は認めら れない。また Gramineae の増加もみられない。このことは，この北海道の秩父別湿原 の周辺では，ほんの最近にいたるまで，農耕活動を伴う顕著な人類の森林破壞はなかっ たものとみることができる。こうした傾向は, 北海道の他の地域の分析結果においても, ほ录同様に認められる。

\section{II-（3） 各地域の分析結果の比較}

さて以上日本各地域に拈ける分析結果をみたが，さらに奄美大島名瀬 (J. Nakamura, 1957), 大分市 “裏川” 河口（畑中健一, 1973), 山口県無田遺跡 (畑中健一, 1971), 濃 尾平野馬飼地区 (中村純, 1972), 静岡県沼津市 (K. Sohma 1965), 千葉県野田市 (J. Nakamura, 1972), 千葉県八日市場市 (安田喜憲, 未発表), 福島県赤井㕣地 (K. So hma, 1961), 青森県小川原湖 (山中三男, 1965) の各地の分析結果を加光, 弥生時代 の日本列島に抢ける植生と人類のかかわりあいについて概観したのが第 7 図である。

64）中村純 (1968)：北海道第四紀堆積物の花粉分析学的研究 $V$, 高知大学学術研究報告, vcl. 17 .

65）中村純・塚田松雄 (1960) : 北海道第四紀堆積物の花粉分析学的研究 I, 一渡島半島(1)-, 高 知大学学術研究報告, vol. . . 中村純 - 山中三男 (1966): 北海道第四紀堆積物の花粉分析学 的研究N, 一礼文島及び利尻島一, 高知大学学術研究報告, vol. 15.

66) Nakamura, J. (1957): "Pollen analyses from two swamps of the Amami islands, Reports of the Usa Marine Biological Station vol. 4.

67）畑中健一（1973）：花粉分析よりみた北九州周防灘沿岸地域の植生变遷, 『西瀬戸内地域大規 模開発計画調查一自然保護利用計画調査一』建設省.

68）畑中健一 (1971)：山口県西海岸低地に拈ける二・三泥炭層の花粉分析, 北九州大学文学部紀 要, vol. 5 .

69）中村純 (1972)：濃尾平野拉よびその周辺地域の第四系の花粉分析学的研究一濃尾平野の研究 との 2 一, 高知大学学術研究報告, vol. 21 .

70) Sohma, K. (1965): "Pollen analysis of the Alluvial deposits of the Tokaido Region", Science Report of Tôhoku U. V. fourth series Biology, vol. 31.

71) Nakamura, J. (1971): "Palynological evidence for Recent destruction of natural vegetation II", Annual Rep. of J. I. B. P. 1971.

72) Sohma, K. (1961): "Pollen analysis of the peat at Akaiyachi moor, Fukushima prefecture", Ecol. Review, vol. 15.

73）山中三男 (1965): 青森県小川原湖付近の第四紀堆積物の花粉分析, 第四紀研究, vol. 4. 
すなわち北九州福岡ではすでに B. P. 4000年以前に人類による植生破壞の痕跡がみら れ，それは人類の農耕活動によって引き起こされた可能性が大であった。 B. P. 2300年 頃にはすでに稲作を伴う広範な森林破䘫が引き起こされており，Shiia，Cyclobalanopsis の森林が切り開かれ，Quercus, Myrica を中心とする二次林が形成されていた。また岡 山県津島遺跡では, 弥生時代前期には Quercus・Pinus を中心とする森林が広がり, 弥 生時代中期に入ると二次林的性格の強いCryptomeria · Pinus を中心とする森林に変っ た。しかも全出現花粉中 $40 \mu$ 以上の截培種と思われる Gramineae の花粉が最も高い出 現率を示し，人類の開田作業などによって，遺跡周辺の植生はかなりの程度破壞されて いたことが想定された。岡山県上東遺跡においても, 弥生時代後期の人々の居住により, これまで優占していた Cyclobalanopsis を中心とする森林が切り払われ，かわってRumex, Chenopodiaceae, Caryophyllaceae, Gramineae などの草本類が生育する荒地が 形成された。また大阪の高梘市安満遺跡では, 遺跡周辺の丘陵地带はイネ科などの陽生 草本が山肌を覆い, 樹木と名のつくのはまばらに生えていたにすぎないと報告された。 また大阪府瓜生堂遺跡に拈いても，これまで生育していた Cyclobalanopsis, Shiia or Castanea を中心とするらっそうとした森林にかわって, 弥生時代中期の人々の居住地 周辺は, Gramineae, Polypodiaceae などの生育するオープンな草原であったことが明 らかとなった。さらに弥生時代の人々が居住している間は, 居住地周辺には森林は回復 せず，人類の森林破壊が顕著であったことを物語っていた。居住地が放棄されると，遺 跡周辺には再び森林が回復してきた。

奈良盆地弥生時代遺跡では，二次植生としてのPinus を30\%以上も 出現する遺跡が あり，遺跡によっては周辺の植生がかなり人為的改変を受けていたと考光られる。

三重県上箕田遺跡においても，弥生時代前期～中期初頭にかけての Shiia, Cyclobalanopsis を中心とする森林が，弥生時代後期に入ると人類の森林破壊の影響を主要因とし て, Cryptomeria, Pinus, Quercus を中心とする森林に転化したことが考えられた。弥 生時代後期にはこらした人類の森林破壤に伴って森林の絶対量が減少し, 野生のイネ科 草本を多量に生育させるような荒地が形成されたことが明らかとなった。

しかし，この伊勢湾沿岸の上箕田遺跡周辺の環境は, 大阪湾沿岸の安満遗跡・瓜生堂 遺跡の環境よりは，より森林密度の高い環境であったとみられた。こうしたことは，さ らに東方の静岡県伊場遗跡についてもいえた。すなわち, 伊場遺跡においては, 弥生時 代後期になっても遺跡背後の丘陵には Cyclobalanopsis を中心とする 常緑広葉樹林が生 育しており，人類による明白な森林破壊の痕跡を認めることは出来なかった。従って同 


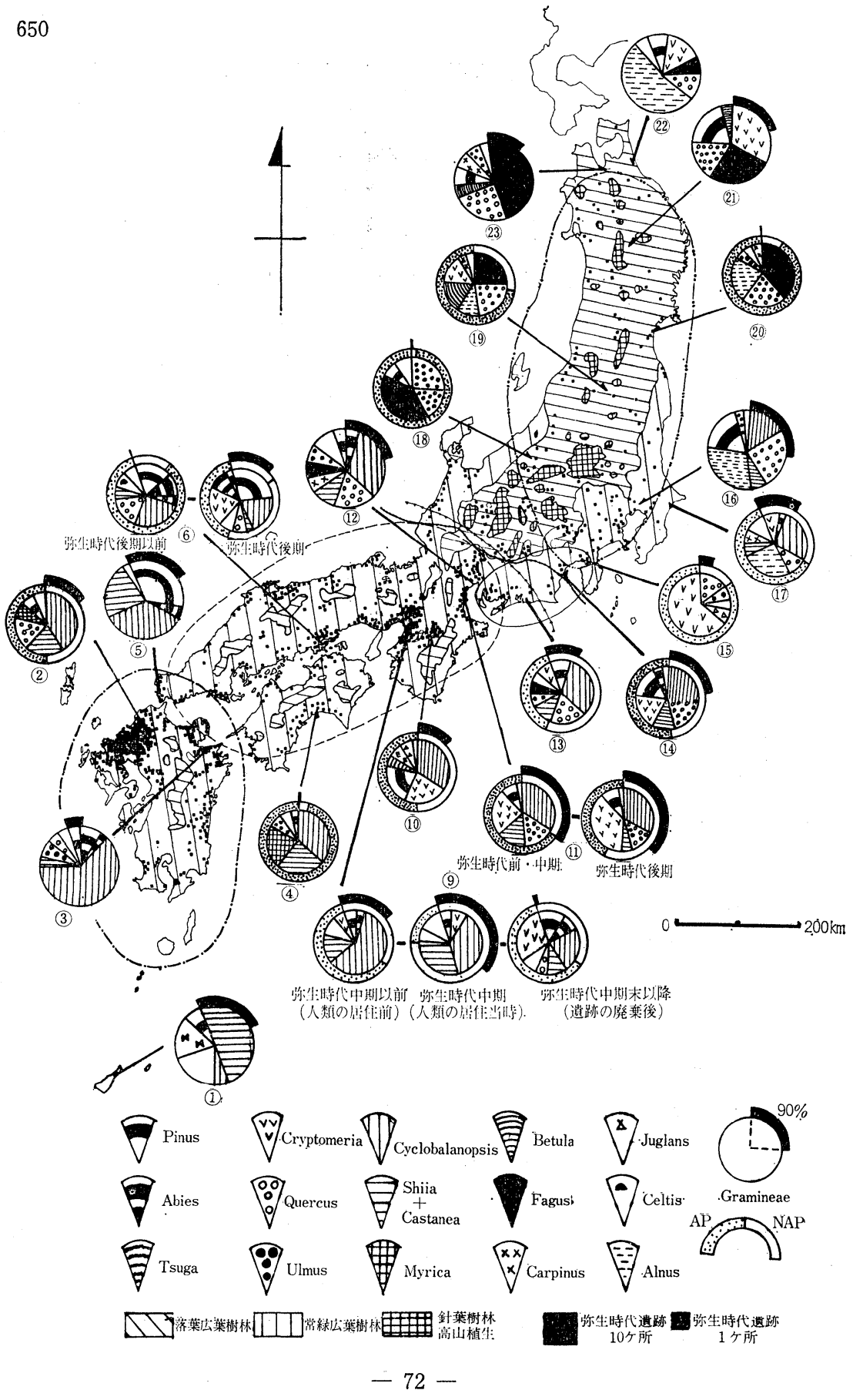


第 7 図 弥生時代の日本列島の植生と遺跡分布

弥生時代の遺跡分布は正確をきしがたいが，大略の傾向はとらえ得ると考える。 図中の (1) (22)の番号は第 6 図の花粉分析試料の採取地点之対応する。 なお，図中の破線で示した弥生時代の文化圏と植生との対応関係については, 拙稿：「弥生時代遺跡の花粉学的研究」立命館文学（投稿中）にて詳述した。

じ常緑広葉樹林帯にありながら，大阪湾沿岸・瀬戸内地方に比して，東海地方はいまた 人類の森林に対する影響力は微弱であったとみられる。

こうしたことは，弥生文化の中心が大阪湾沿岸〜瀬戸内地方にあるのに対し，東海地 方はその縁辺に当るといら事実とも矛盾しない。これと同じことは, 高知県の石鎚池の 分析結果に拈いてもいえた。すなわち, 稲作には最も適した気候条件にありながら,こ こでは稲作の導入とそれに伴ら森林破罜の 痕跡が花粉ダイアグラムから読みとれるの は, ょらやく B. P. 1,000年以降になってからであった。

このように, 早くから稲作が伝播し, 人口密度も高い瀬戸内・大阪湾沿岸では, 弥生 時代人の農耕活動に伴う森林破壞の影響力が大であったのに対し, 同じ常緑広葉樹林帯 でありながら，東海地方・南四国などでは，瀬戸内・大阪湾沿岸などの弥生文化の中心 地に比して，農耕活動に伴う人類の森林破壊の規模は小さかったとみられる。

これに対し落葉広葉樹林带にあたる中部山岳地帯の野尻湖においては, 縄文時代人が 古くからかなり密に居住しており, 稲作伝播以前から周辺の植生は一時的に破壊を受け ていた。しかしながら，稲作を伴った人類による広範な植生破壞の時期は，ょうやくB. P. 1, 500年の古墳時代に入ってからであり，この点に沶いては西日本に比してはるかに 遅れをとっている。東北地方の仙台湾周辺の多賀城址に沶いては，花粉ダイアグラムか ら稲作の開始が知られるのは，よらやく 7 世紀後半になってからであった。この稲作の 導入に伴って起こった森林破壊は，まず沖積低地に生育していたハンノキ林の伐採とな って現われた。それはきわめて局地的な様相が強かった。沖積平野周辺の丘陵部に生育 した Fagus, Quercuをを中心とする森林の伐採が広範に引き起こされるのは, 畿内大和 政権の東北進出に伴ら多賀城の築造・条里制の施行などの，一連の社会的変動を待たね ばならなかった。

多賀城址以北の東北地方北部に拈いては, 稲作農業を伴ら人類の森林破壊の出現時期 は,より後の時代に属した。さらに北海道にいたっては, 稲作農業を伴ら人類の広範な 森林破壊の出現は, ほんの最近の出来事であった。

以上の如く日本列島を南から北にいくにつれ，稲作伝播によって引き起こされた森林 破壊の時期と程度は，遅くかつ小規模なものとなっていくことが明らかとなった。稲作 
伝播によって平野周辺の丘陵部にまでわたって広範な植生破壊が引き起こされた時期 は，ここに取り上げた分析結果からみる限り，北九州と東北地方とでは，およそ 1,000 年の隔たりが認められた。九州・瀬戸内・近畿・東海地方の照葉樹林帯にあっては, 弥 生時代後期にはすでに遺跡周辺の植生は人類の手によってかなりの程度改変が加えられ ていた。ところが落葉広葉樹林帯にあたる東北地方の仙台湾周辺では, 弥生時代中期以 降稲作の導入があったものの，稲作農業を伴った人類による森林破壊の程度は小規模 で，平野周辺の丘陵部にはブナ属・ナラ属の原生林が後年まで残ることとなった。稲作 伝播に際して, より自然環境条件の劣悪な, 仙台以北の地域に打いては, こうした現象 はより顕著であった。こらした分析結果をあとめて図示すると，第８図の如くになる。

以上のわずかのデーターからの議論には多くの問題点があり, 取り上げた分析結果が その地域の特性を最もよく反映したものであるかどらかなど，議諭の余地は多いと思 ら。しかし, 稲作伝播による人類の森林破壊が常緑広葉樹林带にあたる西日本において 早くから引き起こされ，かつ大規模であったこと，落葉広葉樹林帯にあたる東北日本で は, その出現の時期は遅く, かつ小規模であったという事実は, 今後分析結果が増加し ても, 大勢に挍いて変らないものと信じる。な扐, 日本列島に拈ける弥生時代の植生分 布と文化圏の対応関係, あるいは当時の栽培作物, 気候環境等については, 別稿にて詳 述した。

\section{III イギリスと日本の比較一むすびにかえて一}

\section{III-(1) 森林破壊の時期}

ユーラシア大陸の東端と西端にあり, 農耕の発生地からはともに辺境地方にあたり, その栽培作物が伝播する過程において北へ向からほど栽培馴化し，かつその伝播に際し ては海路を経なければならず，島内の桩大に拈いては北方ほど農耕に不適になるといら 共通の地理的・生態的条件をもつ日本とイギリスに拈いて，農耕伝播による植物景観変 遷の時期と程度には，以下の如き類似点が認められた。それを図示すると第 8 図の如く になる。

すなわち両島においては, ともに南部ほど農耕伝播によって引き起こされた人類の森 林破壞の時期が早く，かつ程度に捻いても大であった。イギリスでは南部の Shippea Hill (第 2 図) と北部の Bloak Moss (第 4 図) とでは, 農耕の伝播によって最初に引 き起こされた人為的植生破壞の出現時期に, 約 2,000 年の隔たりがみられ，日本では西 南日本の福岡と東北日本の仙台湾周辺とでは，稻作伝播によって引き起こされた広範な

74）安田喜憲 (1974): 弥生時代遺跡の花粉学的研究, 立命館文学（投稿中). 
植生破壊の出現時期には, 約 1,000 年の隔たりが認められた。

また両島内の北部の, いわゆる辺境地方では, 農耕活動を伴った人類による森林破壊 と, 農耕活動の中止による森林の再生が繰り返し認められ, 農耕に不適な環境に人類が 次第に自らのエクメネーを拡大していく過程が，植物景観の变遷から読み取れた。

ヨーロッパの古典文明の花を咲かせた地中海文化に対して，へロドトスは『光は東方 から』と言った。古代文明の発祥地から遠く離れたこのイギリスと日本に稆いては，ま さに『光は南方から』きたのであった。

こうした農耕文化は，イギリスの南部に括いてはAlnus, Quercus, Ulmus を中心とす る森林の中に, イギリスの北部に拈いては Betula, Quercus, Alnus を中心とする森林の 中に導入された（第 5 図参照）。イギリスの新石器時代に拈いては, 一時的な森林破壊 の段階が一般的で, 農耕地の拡大・放棄と森林の伐採・再生が繰り返し認められた。こ のことは，イギリスにあっては南方から伝播してきた農耕文化は，オープンな植生より はむしろらっそうとした森林に取り囲まれた環境の下に導入されたことを示すものであ る。

一方, 日本にあっては稲作が伝播した当時, 九州・瀬戸内・近畿・東海地方にかけて は Cyclobalanopsis, Shiia などを中心とする常緑広葉樹林が, 中部山岳・東北地方に拈

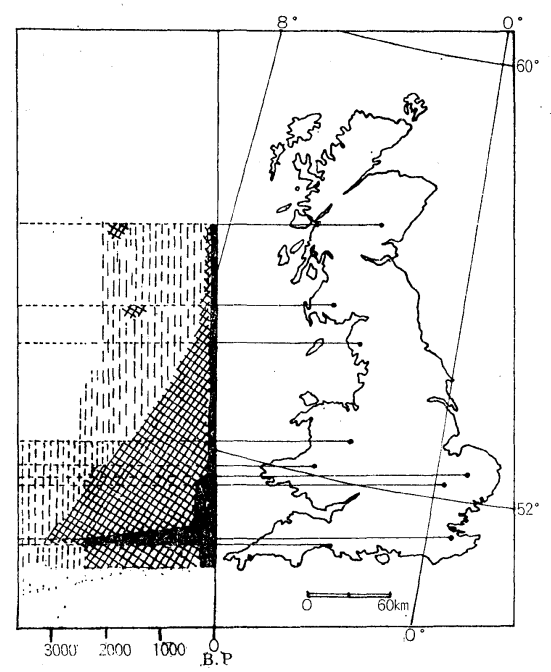

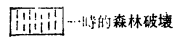

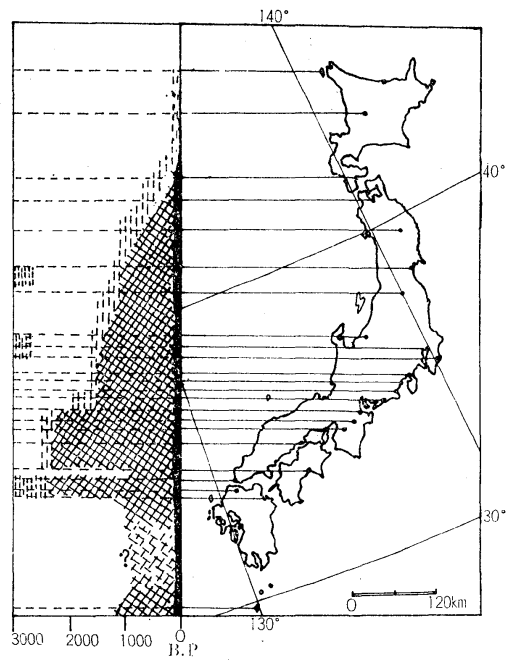

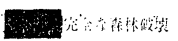

第 8 図イギリスと日本の森林破壊の地域性の比較 
いては Quercus, Fagus, Ulmus, Alnus を中心とする落葉広葉樹林が広がっていた（第 7 図参照)。しかるに 日本列島の西南部に抢沪る弥生時代遺跡の花粉分析結果からは, Gramineae, Artemisia, Cyperaceae, Polypodiaceae などの草本類・羊米類の出現率が 高い。したがって日本に拉ける稻作の導入は, イギリスに比してよりオープンな植生の 下に行なわれ，居住地周辺には Artemisia, Gramineae, Polypodiaceae などが生育す る荒地が展開していたとみることが出来る。

こうした農耕伝播時におけるイギリスと日本の居住地周辺の森林相の違いは，イギリ スへ農耕文化が伝播した時代が B. C. 3,000年前後の 新石器時代であったのに対し，日 本へ稲作が伝播したのは, イギリスよりはるかに後の, 青銅器時代から鉄器時代にかけ てであることを考台わせれば，当然のこととも言える。イギリスにおいても鉄器時代 に入ると，広範な植生破壊の段階が一般化してくるのである。

しかし，こうしたイギリスと日本の農耕伝播に際しての時代的な差以外に, 片や家畜 を伴ら地中海農耕文化であり，片や稲作を中心とする農耕文化であるという，農耕形式 の違いが，居住地周辺の植生環境を決定する上で，大きな役割を果たしたものと考学ら れる。すなわらイギリスにおいては, 森林のらっそうと茂る丘陵こそが, 農耕を営むの には最も適した場所であった。これに対し, 稲作農業を中心とする日本にあっては, 絶 えず洪水氾濫があり，ために大森林が形成されず，ヨシなどが生育する 沖積平野こそ が，最も適した生産の場であったのである。したがって，イギリスにおいては，生産に 適した丘陵地を選ぼらとすれば必然的に大森林のまっただ中での生活を余儀なくされた のに対し, 日本にあっては, 居住の当初から, 居住地周辺にはヨシなどが生育する比較 的オープンな景観が 展開していたものとみられるのである。したがって, 佐々木高明 (1971) が明らかにした稻作以前の, 縄文時代に新ける焼畑農耕の存在を仮定すれば, おそらく縄文時代人たちは，イギリスの新石器時代人と同様に，らっそらとした森林の 中で, 山地林を焼き払いながら農耕を行なっていたものと考えられよう。

このようにイギリスと日本の農耕形式の違いは, 居住地周辺の植生環境を決定する上 で大きな役割を果たしたことが考劣られたが，この農耕形式の違いは，イギリスと日本 に和汗る人類の森林破壊の様式にも，大きな違いをもたらしている。

III-(2) 森林破壊の様式

75）佐々木高明 (1971)：前掲.

76）イギリスの新石器時代人や縄文時代の人類が焼き払った森林は主に山地林であったのに対し, 稲作伝播以後の弥生時代の人類が破壤した森林は主に平地林であったことは, 今後, 人類の森 林破垻を考察するに際し，注意されなければならない点である。 
すなわち,すでに述べた如く, ヨーロッパの地中海農耕文化は, 粗放的で多くの農耕 地特有の雑草がみられ, 花粉分析によって農耕の伝播を探る際にも, この雑草花粉の出 現が大きな役割を果たしていた。つまりイギリスに拈いては，農耕の伝播を示す Gramineae 花粉の出現は, 必ず Artemisia, Plantago, Compositae, Rumex, Chenopodiaceae, Pteridium などの雑草花粉の増加を伴っていた。そうしてこの雑草類には, 農耕 地に特有な Artemisia, Compositae, Rumex などと, 牧草地に特有な Plantago, Pteridium などが区別され，これらの雑草花粉の出現率の変化から農耕形式の変化を適確に つかむことが出来た。すなわちイギリスでは, 民族移動に伴って, 穀物栽培に主体をお く農業と牧畜に中心を敃く農業が，先史・歴史時代に交互に繰り返し現われてきたこと が，花粉分析によって明らかにし得たのである。また農耕の導入・発展に伴ら Gramineae の花粉の増加は明膫で, この Gramineae 花粉の木本花粉に対する 出現率から, 人類による植生破壞の段階を明白に論ずることが出来た。

これに対し，日本に拈いては稲作伝播に伴う Gramineae 花粉の增加と, 強固な結合 をもつ雑草花粉は，低湿地に生育する野生の Gramineae, Persicaria, Cyperaceae, Osmunda, Polypodiaceae や荒地に生育する Rumex, Umbelliferae, Artemisia, Compositae などであった。その場合，特にイギリスにおいては，Artemisia， Plantago， Rumex, Compositae など比較的乾燥した荒地に生育する雑草が多かったのに対し, 日 本に执いては低湿地に生育する野生の Gramineae, Cyperaceae, Persicaria, Polypodiaceae, Osmunda などの出現率が高く, イギリスと日本に抢ける農耕形式の違いが, 雑草花粉の出現状態の違いとしても反映されていることが明らかとなった。

また農耕の伝播を指示する Gramineae 花粉の出現状態についてみても, 生産活動の 中心が沖積低地にあった日本に招いては，栽培種の稲・麦などが伝播する以前からその 地域にはイネ科のヨシなどが生育して拉り, Gramineae の出現は必ずしも農耕の伝播 を意味しなかった。したがって日本にあっては，Gramineae の出現率から農耕の伝播 を論ずるには, 多数のこうしたイネ科花粉の中から栽培種の花粉を区別する必要がめっ た。こうした栽培種と野生種を区別するにあたっては, 現時点に就いてはイネ科花粉の 花粉粒径による区別しか方法がなかった。この点については, 今後, 電子顕微鏡の利用 など新しい技術の導入が切望された。

一方，木本花粉についてみると，イギリスでは農耕活動を伴う人類の影響によって， Quercus, Alnus, Ulmus などの花粉が減少した。とりわけ特徵的なのはUlmus の花粉 の減少である。気候変化に関係なく, この Ulmus の花粉が減少した場合は, イギリス 
においては農耕が伝播したとみることが出来た。なぜなら，地中海農耕はイギリスへ伝 播した当初から家畜を伴っていたが，このUlmus の樹皮や樹葉はこうした家畜にとっ て最も好適な飼料となったからである。

これに反して，農耕の伝播に伴って顕著に増加する木本花粉もあった。それは Corylus である。この Corylus は, いわゆる“踏みつけ植生”で，家畜などに踏まれること によって逆にその生育地を拡大するものである。したがって,イギリスの南部諸地域な どにおいては，農耕伝播に伴うこの Corylus の増加は特に顕著であった。このように， イギリスにおいては, 農耕伝播に伴ら人類の森林破塆に際しては, 家畜による植生破壤 が大きなウェートを占めていた。

一方, 日本の場合, 西南日本に抢いては Shiia, Cyclobalanopsis を中心とする常緑広 葉樹林が，東北日本に拈いてはFagus，Quercus，Ulmus を中心とする葉葉広葉樹林が， 稲作伝播によって切り開かれていった。その際, 農耕活動に伴ら火入れ以外に, 唐古遗 跡・登吕遺跡・上箕田遺跡・多賀城址などでみられたよらに，開田のための土木用材・ 木工具, あるいは建築材入手のため森林を切り開くことが, 人類による森林破填の中で 大きなウェートを占めたものと思われる。

したがってイギリスに招いては，人類の森林破壊は自らの居住地と農耕地の扗大を意 味し, 一旦破壊された森林は農耕地が放棄されない限り再生することはなかった。これ に対し，日本にあっては,森林の破壞はイギリスほど直接的に農耕地の拡大に結びつかず， 丘陵地の森林は森林資源の供給地にはなったものの, 森林伐採地が農耕地として利用さ れる程度は, イギリスに比してはるかに少なかったものと考えられる。このため, 日本 に打いては, 稲作伝播に伴う人類の森林破壊は沖積平野周辺の平地林の絶対面積を減少 させはしたが，それ以外の山間部・丘陵地の森林は一旦切り開かれたものの，その後に Pinus, Cryptomeria などの三次林が再び生育することになった。日本の稲作伝播に伴う 人類の森林破垻は，森林の絶対面積を減少させる以上に森林の構成種に大きな変化をも たらしたとみることが出来る。さらに，瓜生堂遺跡に拉いて典型的に認められたごとく 日本はイギリスに比して気候が温曖かつ湿潤であることも, 森林の再生をより容易にし た。

したがって,イギリスに打いては, 第 3 の完全なる植生破壞の段階が明瞭であったの に対し, 日本ではこの第 3 の段階は明瞭でなく, 現在の植物景観を形づくった植生変革 はPinus の急增するところに求められ, イギリスのように森林面積の絶対的減少を意味 しなかったのである。 
こうしたイギリスと日本の農耕伝播によって引き起こされた人類の森林破壊の様式の 違いは，まさしく，片や農業の開始期から家畜を飼い，粗放的で特有の雑草群を作り上 げている農耕であるのに対し，片やその生産の場が大河川の下流域の沖積平野にあり， 家畜を伴わず，材木を多量に使用する土木工事を伴う農耕形式をとるという，イギリス と日本に拈ける農耕形式の違いによって生じたものに他ならない。

以上の如く，イギリスと日本の比較といらマクロな観点からみた場合，一般にこうし た事実が言えるものと考学る。しかしより小さな空間的スケールで考察した場合には， 各地域の様々な地域的条件によって，より小規模な地域差が現われる。こらした小さな スケールでの植物景観変遷の問題については, 仙台湾周辺をフィールドに拉き, 近く報 告の予定である。

本稿を能登志雄先生にささげます。

本稿をまとめるに際し, 終止ご指導下さった東北大学理学部地理教室西村嘉助教授, 花粉分析に ついてご指導下さった同生物理学教室相馬寛吉助教授, 考古学についてご指導下さった文学部考古 学教室芦沢長介教授に厚く和礼申し上げます。また，たえずはげましと有益なご助言を下さった立 命館大学文学部地理学教室谷岡武雄教授・日下雅義助教授, 国立民族学博物館佐々木高明教授に厚 く扰礼申し上げます。東北学院大学藤井啓子さんには原稿の整理・清書をしていただいた，未筆な がら記して感謝いたします。

(広島大学総合科学部環境科学)

77）この点については，安田喜憲（1972）：「仙台湾周辺に拈ける 古代の植生と居住空間」『人文 地理学会秋季学術大会要旨』を参照されたい。 